
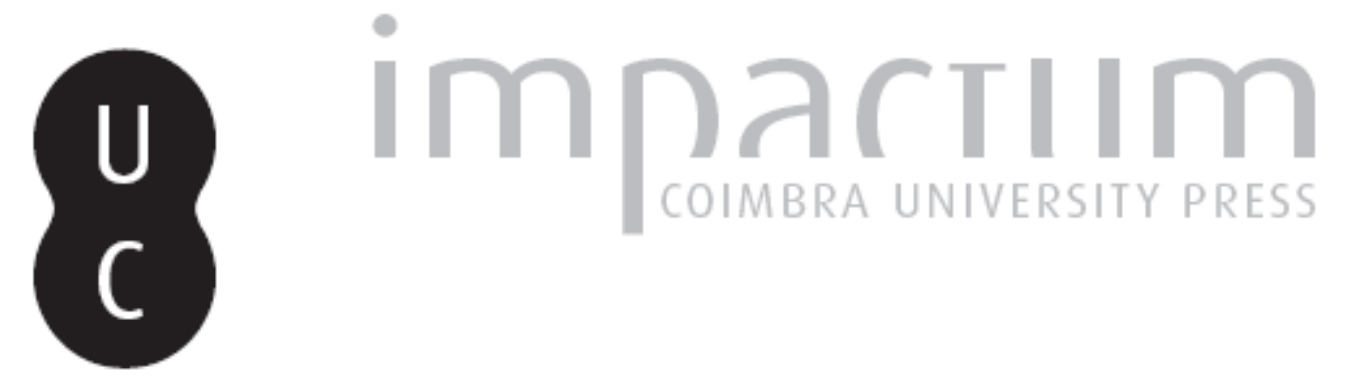

Três teses sobre a Ucronia e a Floresta Utópica: a propósito do Integralismo Lusitano Autor(es): $\quad$ Archer, Paulo

Publicado por: Imprensa da Universidade de Coimbra

URL persistente:

URI:http://hdl.handle.net/10316.2/43723

DOI:

DOI:https://doi.org/10.14195/2183-8925_24_10

Accessed : $\quad$ 26-Apr-2023 16:04:45

A navegação consulta e descarregamento dos títulos inseridos nas Bibliotecas Digitais UC Digitalis, UC Pombalina e UC Impactum, pressupõem a aceitação plena e sem reservas dos Termos e Condições de Uso destas Bibliotecas Digitais, disponíveis em https://digitalis.uc.pt/pt-pt/termos.

Conforme exposto nos referidos Termos e Condições de Uso, o descarregamento de títulos de acesso restrito requer uma licença válida de autorização devendo o utilizador aceder ao(s) documento(s) a partir de um endereço de IP da instituição detentora da supramencionada licença.

Ao utilizador é apenas permitido o descarregamento para uso pessoal, pelo que o emprego do(s) título(s) descarregado(s) para outro fim, designadamente comercial, carece de autorização do respetivo autor ou editor da obra.

Na medida em que todas as obras da UC Digitalis se encontram protegidas pelo Código do Direito de Autor e Direitos Conexos e demais legislação aplicável, toda a cópia, parcial ou total, deste documento, nos casos em que é legalmente admitida, deverá conter ou fazer-se acompanhar por este aviso. 

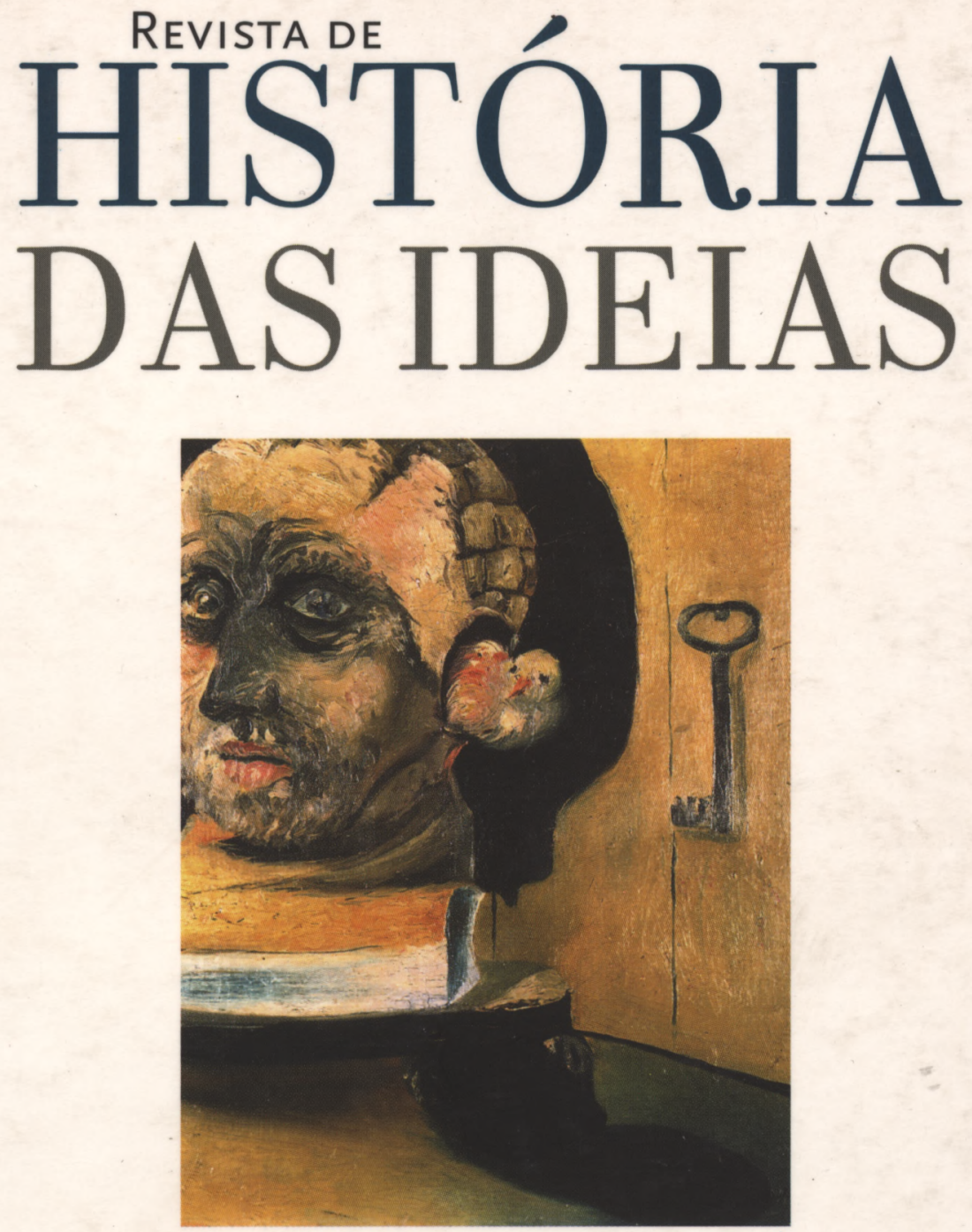

OS INTELECTUAIS E OS PODERES

Volume 24, 2003

INSTITUTO DE HISTÓRIA E TEORIA DAS IDEIAS

Faculdade de Letras da Universidade de Coimbra 


\title{
TRÊS TESES SOBRE A UCRONIA E A FLORESTA UTÓPICA A propósito do Integralismo Lusitano
}

\author{
"Entre o que vive e a vida \\ P'ra que lado corre o rio?" \\ Fernando Pessoa \\ "Liberdade e libertação são uma tarefa \\ que nunca acaba" \\ Umberto Eco
}

Um dos problemas nucleares suscitados por alguns estudos de história intelectual, das ideias e da cultura, consiste na decifração do lugar e das relações que entre si os movimentos dos intelectuais articulam. Uma abordagem possível consiste em estruturar essas relações em função do paradigma (histórico e social) que utiliza os instrumentos teóricos de campo, de esfera política e de espaço público (Roger Chartier) conjugados com as teorias, não apenas estéticas, de recepção. E num quadro, em que, na história intelectual contemporânea ou, numa denominação mais abrangente, na história das ideias e das mentalidades (que, num mundo crescentemente letrado, cada vez mais se foram enraizando em gestos,

\footnotetext{
* Professor do Ensino Público Politécnico.
} 
em leituras, em imaginários originados, também, nesse microcosmos dos intelectuais), a solução do problema da modernidade e da antimodernidade, como refere Jeffrey Herf, reencontra uma perspectiva ética que parece ter sido ocultada pela linguagem críptica das ciências sociais, que, uma vez (de)cifrada, vai perdendo algo da sua dimensão crítica e da sua função interpeladora. Foi a crítica soterrada, de igual modo, pela vulgarização de certas conviç̧ões necessitaristas, que alastraram, também, por áreas hegemónicas da historiografia produzida no século $\mathrm{XX}$ (sobretudo na sua versão historicista, a de um cientismo teleologista, eufórico ou apologético) - e por certas "ruminações filosóficas sobre a modernidade", que anulam, ou pretenderam anular, a autodeterminação do juízo sobre o passado, como se passado não fosse já uma escolha por certo caminho significante na densa floresta das narrativas e dos imaginários sociais, opção por uma perspectiva heurística e tomada de decisão hermenêutica, ou expressão cultural da própria fenomenologia da autodeterminação do juízo, isto é, da capacidade autodeterminante dos indivíduos.

É esta a fixação de sentido que o presente estudo pretende estabelecer, analisando um dos movimentos de intelectuais mais significativos do século $\mathrm{XX}$ português, até pela doutrina que produziu e que se plasmou, em grandes áreas, através de mediações menos esclarecidas, em quotidiano e em poder, durante meio século. Autodefinido desde o início, o Integralismo Lusitano, como um movimento elitista de intelectuais (antiliberais, anti-republicanos, antidemocráticos e anti-socialistas), procurou, em certa fase da sua evolução política (entre 1917-1919 e a partir de 1921) a articulação e a afirmação como movimento de massas. Refira-se esta contradição essencial entre teoria e praxis política, fazendo, por vezes, porque parece ser esse o local (na tradição complicativa de Coimbra), o elogio da teoria (sem o qual toda a teoria e verificação empíricas não fazem sentido), observando, ao mesmo tempo, como a tentação das massas seduziu aqueles intelectuais elitistas que, durante o seu percurso pela juventude e pela universidade, reactualizando certo imaginário de rara avis nefelibata da outra geração, a de António Nobre e de simbolistas, se constituíram num esotérico grupo esvoaçando sobre os velhos telhados das cidades.

Diga-se que a adopção do conceito de massas surge na asserção de um novo sujeito histórico (já não é o "povo" de Thierry e de Herculano, nem o "sujeito colectivo" de Michelet) e de um novo conceito histórico e 
social emergente na Europa entre a tradição nietzschiana do niilismo finissecular e o dealbar do século XX, com Max Weber, Sigmund Freud, Georges Sorel, Ortega y Gasset ou Jung e Wilhelm Reich, ou, noutra perspectiva, com Paul Bourget e Gustave Le Bon, que exploram, os primeiros, certas concepções sociológicas oriundas do marxismo analítico ou do sindicalismo e do anarquismo finisseculares, e os segundos, certa irracionalidade e espontaneidade dos movimentos das multidões e das ruas - a que corresponde o último momento da pressão de alargamento, no interior das sociedades burguesas, do conceito de espaço público e da sua própria gestação, ancorada no alargamento da opinião pública (Jürgen Habermas). Por outras palavras, o conceito de massas, reflecte, sob a perspectiva sociológica, política e filosófica, uma "fórmula de idealização horizontal", como refere Peter Sloterdijk, cujo plano de continuidade funcional passou pelo encaminhamento das multidões - onde os indivíduos desarticulados trocam a sua condição de impotência (imbecilitas, in-potentia) por um "desamparo organizado" (Hannah Arendt) ${ }^{(1)}-\mathrm{de}$ modo a que estas ondas de multidão se parecem encaminhar para a via única do culto do líder, movimento típico "unitário" da primeira metade do século XX (embora tenha conhecido, extensas reactualizações diacrónicas), para depois desaguar nessa espécie de culto do estrelato que alimenta as massas ansiosas por entretenimento ${ }^{(2)}$, de distracção, ou, de qualquer forma, e por qualquer preço, de contínua, mediática, alienação (panem et circensis), característica de uma cultura assimptótica, porque virtual (Baudrillard) e esfíngica, que se tem desenvolvido desde a metade do século $X X$ até ao presente. Enquanto a densificação (Elias Canetti) da mancha na rua marcava a atraç̧ão, o isolamento simultâneo, a dispersão, parece marcar agora a distracção.

Se o substantivo plural "massas" tenta traduzir conceptualmente, desde os finais do século XIX, uma nova realidade sociológica, também o termo "intelectual", não na sua forma adjectiva, mas substantiva, parece inexistente (ensina o velho exemplar de Os intelectuais, de Louis Boudin)

(1) Hannah Arendt, Elemente uns ursprung totaler Herrschaft, apud Peter Sloterdijk, Die verachtung der massen (Versuch über kulturkämpfe in der modernen Geselschaft), trad. cast., El desprecio de las masas. Ensayo sobre las luchas culturales de la sociedad moderna, Valencia, Pre-textos, 2002, p. 25.

(2) Peter Sloterdijk, El desprecio de las masas, ob. cit., pp. 24-25. 
no panorama cultural e lexical, antes de surgir em França a belle époque e Cézanne - e nem os dicionários oitocentistas o registam. É um problema curioso.

Com efeito, o Dictionnaire complet illustré, de Pierre Larousse (o que está sobre a mesa é de 1898), continua a registar, além das formas adverbiais "intelectuellement" $\mathrm{e}$ "intelligemment", apenas a arcaica formação adjectiva. E só em 1909 um desses cartapácios, assegura, por seu lado, Boudin, inclui a forma substantiva de "intelectual", indício, portanto, de que o caso Dreyfus (que, contou com o não menos célebre Manifesto dos intelectuais, aparecido no Aurore de 14 de Janeiro de 1898, subscrito por uma legação de escritores, historiadores, pensadores, com Zola e Anatole France, à cabeça e Blum e Seignobos, ou Lanson e Herr, pelo meio), tinha remetido para o areópago dos dicionários um novo nome, porque havia uma ideia nova e um novo sujeito portador. Winock, que utilizarei um par de vezes neste estudo, também faz remontar o seu Século dos intelectuais a 1894 e à eclosão do processo Dreyfus, enquanto Cristophe Charle situa o "nascimento" do intelectuais nas décadas de 1880 a 1900; Bourget falava já de história intelectual a propósito do Roman russe (1886) de Vogüé(3).

O próprio Gustave Lanson na sua Histoire de la littérature française, apesar de ter subscrito aquele manifesto de intelectuais, não utiliza o termo uma única vez, mesmo quando, no seu IV livro, se dedica ao estudo da crise do naturalismo e ao crepúsculo das escolas literárias, que é como quem diz, ao epilogo da literatura descomprometida. Apenas constata que, por 1900, desaparecera a figura do écrivain dilettante e com ele, a littérature désintéressée ${ }^{(4)}$, muito embora, em toda esta parte do denso volume se compreenda que, com a liquidação do simbolismo e do lirismo egotista, escrita que não reflectisse as lutas sociais e políticas não mais era "literatura", nem seus autores "escritores". Alguém mal intencionado poderia dizer que, afinal, os escritores não são intelectuais, o que não é verdade, evidentemente. A não ser que seja sua a vox clamantis in deserto parece que os escritores, os que mais gozam os favores da opinião pública,

(3) Philippe Joutard, "L'ouverture des connaissances et les mutations culturelles. 1871-1914", in Georges Duby (dir.), Histoire de la France des origines à nos jours, Paris, Larousse, 1995, p. 788.

(4) Ob. cit., Paris, Hachette, 1922, pp. 1113-1114 ss. 
corporizam mesmo o paradigma do intelectual, em eras anteriores ao triunfo dos génios da Microsoft (outro erro vulgar é considerar que, exceptuando Einstein ou Reeves, astrofísicos e matemáticos não são intelectuais. Nada mais grosseiro. Eles são os intelectuais dos intelectuais, excepto quando não são mesmo). Se o meu dicionário de português e de latim, mais antigo do que o Vocabulaire philosophique de Lalande (1909), não errar, no último quartel do século XIX fazia-se a retroversão de "intelectual" apenas pela sua forma adjectiva, isto é, ad intellectum pertinens, como coisa relativa à inteligência; o que prova (e é coisa nenhuma), não terem conhecido os romanos, no tempo de Ovídio, nem teólogos e juristas, no tempo do latinório académico, o substantivo; e os dicionaristas, ao tempo em que Camilo Pessanha escreveu os primeiros versos, posteriormente incluídos em Clepsidra, também não. Outros dicionários de português do século XIX nada acusam, a máxima de Boudin parece empiricamente confirmada: nem os de português e francês registam o termo, como no Dictionnaire de Roquette ${ }^{(5)}$, onde "intelectualidade" aparece correspondida, apenas, por faculté intellective. De facto, se Diderot, no seu ensaio setecentista, Réflexions sur les langues, tivesse razão, le vocabulaire d'une nation est une table assez fidèle de toutes ses connaissances, embora se reconheça que essa espécie de bíblias conservadoras das línguas demoram seu tempo a acolher novos termos e testamentos novos.

Ora, que se saiba, Espinoza, Kant ou Hegel, não eram, no rigor vocabular, intelectuais (contudo, o fossem), porque eram ainda filósofos, representantes de uma velha diferença antropológica que distinguia o "sábio" (sapiens sapiens) do "insipiens vulgus". O Aufklärung, com o seu programa de vulgarização filosófica e a sua crença no poder desocultador da razão, não atenuou essa diferenciação: no século XIX, Comte, Littré e Renan são intelectuais, hierocratas, sociocratas, de uma nova cultura laica. Marx é mesmo o paradigma do intelectual autoevidente que profetiza sobre o futuro, e grande parte dos intelectuais, no século $X X$, andou, estranhamente, a discutir o sentido histórico e filosófico dessas profecias do passado.

Nem é preciso exagerar: foi Camões, no século XVI, entre outras coisas mais significativas, um extraordinário mestre de mitologia clássica,

(5) Editado em Paris pela V. ${ }^{\text {ve }}$ Aillaud, Monlon \& C. ${ }^{\text {ie }}$, em 1858 , cuja primeira edição é de 1841 . 
mas não era propriamente um "intelectual". Isto põe-nos de sobreaviso, por exemplo, quanto ao rigor conceptual que subjaz a certas histórias dos intelectuais na Idade Média que são, assim, o equivalente cultural da história da fotografia na Época Clássica (porque está íncita na noção contemporânea de intelectual um munus dessacralizado, embora possa, ou não, ser sacralizador nos seus propósitos). E os que liam Espinoza, Cervantes ou Hegel (podendo ou não compreendê-los, e isso já é outra questão), por meados do século XIX, não eram ainda intelectuais, senão parte da "opinião ilustrada do país" (como aparece a designação no panfleto estudantil de Antero, 1862) - enquanto a questão coimbrã parece documentar a excelência de uma verdadeira querela de intelectuais, avant la lettre, o que é lexicalmente verdadeiro; e os vencidos da vida documentam o perímetro restritivo do campo de intelectuais elitistas. No tempo de Almeida Garrett, e no tempo em que havia amêijoas selvagens e românticas, descrito por Bulhão Pato, existia uma classe de literatos que se reunia em salões literários, muito embora alguns fossem, como os próprios, "intelectuais políticos", que intervinham na res publica, influíam na formação da opinião pública, enquadravam-se nos clubs e nas formações partidárias (ou os renegavam), preparavam os destinos legislativos do estado-nação liberal, que se travavam em batalhas ideológicas como se fossem guerras civis, e em guerras civis com o ímpeto de uma polémica literária. Em duas palavras, como compõem para convencer (Chateaubriand, Novalis, Byron, Alexandre Herculano), são os intelectuais, neste sentido, os filhos dilectos do romantismo. Herculano é mesmo o caso do intelectual paradigmático do século XIX: ele unificou (e cindiu) as memórias nacionais, através de uma historiografia poderosa e criou uma comunidade imaginada nos romances históricos; polemizou a favor da liberdade de pensamento, arregimentou os intelectuais laicos contra o poder simbólico da Igreja e da Universidade, ainda de tipo clerical, criando um espaço novo de debate político e das ideias; discutiu publicamente os seus fundamentos filosóficos e ideais políticos. Assim, a própria emergência da nação moderna parece ser indissociável do nascimento do "intelectual"(6).

(6) Cf. Tom Nairn, "La maldición del ruralismo: los limites de la teoría de la modernización", in Jonh A. Hall (ed.), Estado y nación. Ernest Gellner y la teoría del nacionalismo, Madrid, Cambridge University Press, 2000, p. 166 e nota 32. 
Mas este critério analítico da intervenção é perigoso quando transposto para o século XX: ninguém, na história intelectual e na cultura do século, a ponto de ter criado um paradigma da percepção do mundo radicalmente novo, promoveu (agora) mudanças culturais e mentais tão significativas na sociedade portuguesa como o ignorado Fernando Pessoa. No entanto, talvez não seja Pessoa um intelectual típico. Mesmo quando ministrados, em doses cavalares, excertos da Mensagem nas escolas finais do Estado Novo, nunca foi elevado à categoria de patriarca, pai fundador, nem de oráculo - muito menos de intelectual orgânico. Mas não houve, tirando aquele mestre de mitologia (que falava de uma nação de navegação com um estado anão), poeta mais internacionalista e nacionalista, ao mesmo tempo e, por vezes, na mesma página.

Ora, aqueles literatos mundanos de oitocentos (João da Ega, por exemplo, ou Pinheiro Chagas, em carne e osso) tinham substituído os ilustres, nomenclatura que se coadunava mais com o imaginário honorífico, com o estamento típico dessas sociedades-contadores de Antigo regime (metida em cada gaveta existia uma certa qualidade de pessoas, avaliáveis, como hoje, pela quantidade de coisas, materiais e simbólicas, que possuíam). Os ilustres, são, por sua vez, a reminiscência, de tratamento e de cortesia, de uma desaparecida nobreza de toga que, glorificando os preclaros príncipes, à sua sombra ascendia - e à sombra da sapiência ascendia numa sociedade de ignorantes (na qual, os que liam, lectores ou lentes, eram tão raros que se destinguiam pelas suas sobre-humanas faculdades de decifração de papeis grafados com tintas pretas); em última análise, são estes os herdeiros dos clérigos, dos copistas, dos ermitas, meio sábios, meio sagrados, que se associaram em escolas e universidades medievais. $\mathrm{E}$ até $\mathrm{o}$ conde toscano Libri-Caruci, grande apreciador de livros e de bibliotecas inteiras ${ }^{(7)}$, a ponto de os roubar (aos livros) e de as limpar (às bibliotecas), completas, em meados do século XIX, não pode ser considerado um intelectual, mas apenas um bibliófilo. É certo que fez do livro um proveitoso modo de vida, mas isso nada diz do que quer que seja um intelectual. É apenas alguém que se aproveitou de um contacto casual com livros, como acontece aos que os arrecadam e republicam (sem no entanto perceberem bem, ao certo, para que coisa servirão).

(7) Alberto Manguel, Uma história da leitura, Lisboa, Presença, 1998, pp. 245-48. 
Mas outra conotação, na sua trágica dimensão, para o termo "intelectual" só encontrará inteiro significado em pleno século XX. Evocar um episódio conhecido chega para ilustrar essa conotação. Quando, em plena Guerra civil, em Outubro de 1936, as autoridades militares e religiosas, enquadradas pelos nacionalistas de Franco, numa amálgama com falangistas e carlistas, dominando já a cidade de Salamanca, se aprestam, no dia da "fiesta de la raza", a comemorar a descoberta colombiana, num ambiente de exaltação nacionalista e de encenação místico-militar (que fora precedido por semanas de barbárie em cidades e campos da Estremadura e salamantinas), o reitor da Universidade, onde a cerimónia se realizava, Miguel de Unamuno, velha glória das letras espanholas - que escrevera a mais bela tentativa alguma vez feita de interpretação de Cervantes e de Quixote - e sumo sacerdote, conservador, da geração de 98 , responde aos discursos oficiosos, fazendo a apologia da paz, referindo, a certo passo, mutilados militares que apenas teriam o gosto de multiplicar mutilações nos outros, sem compreenderem a "grandeza espiritual de Cervantes", alusão, que foi, directa ao general Millán Astray, fundador da legión extranjera, que ali se encontrava, tal emblema nacionalista na lapela de Franco, mutilado de guerra, de pala preta ao olho, sem braço e sem dedos na mão sobejante. Subitamente interrompido pelo próprio Astray, com gritos de "Mueron los intellectuales!" e de "Viva la Muerte!" (o lema legionário que inspirou Buñuel e Arrabal) no que foi secundado por uma multidão de aplausos e berros de camisas azuis e de legionários, entre gritos de morte contra os "falsos intelectuais", foram-lhe apontadas armas de fogo enquanto o cercavam as milícias fascistas. Não tendo mais tempo, nem possibilidade de discurso, ainda concluiu Don Miguel: "Éste es el templo de la inteligencia. Y yo soy su sumo sacerdote. Estáis profanando su sagrado recinto. Venceréis porque tenéis sobrada fuerza bruta. Pero no convenceréis. Para convencer hay que persuadir. Y para persuadir necesitaríais algo que os falta: razón y derecho en la lucha". Retirando-se entre a multidão nacionalista irada (pelo braço de Carmen Franco, entre gritos de Rojo e de Traidor), guardado dia e noite por força militar, demitido do reitorado, a pedido da "junta" da sua própria Universidade, morreria dois meses depois, quase incomunicável, no profundo desgosto, dizem os biógrafos, de ter assistido ao ferrolho da Espanha e ao desmoronar de todo o sentido da sua vida. Passados uns meses, os nacionalistas criaram um campo de concentração para internar republicanos, anarquistas e comunistas, que denominaram 
“Unamuno"(8). Na semiótica, nada metafórica, do poder das armas, seria este o local simbólico adequado para o internamento dos intelectuais.

Serve a excursão de rodapé para referir um dado fundamental: nas sociedades letradas do século do triunfo da civilização burguesa, os intelectuais ganham prestígio, visibilidade, poder. É como reflexo da visibilidade que adquirem ou do poder simbólico (um habitus do ter teórico, uma postura, dizia Bourdieu ${ }^{(9)}$ ) no qual se investem, já no século $\mathrm{XX}$, como foi o caso referido, que começam os intelectuais a constituir uma "ameaça" que é preciso abater. Ora, é sabido como no século XIX o poder dos intelectuais, de Comte a Marx, de Proudhon a Antero, de Renan a Nietzsche, se rebelou, sobretudo, contra a transcendência, a ideia de eternidade ou aquilo a que Max Weber, chamará, pouco depois, a hierocracia religiosa, não só acentuando as fracturas que as revoluções inglesa e francesa tinham instaurado nos séculos XVII e XVIII, mas provocando também verdadeiras deslocações da sacralidade quer no terreno da experiência estética ${ }^{(10)}$, quer, e do mesmo modo, nos territórios (cuja domesticação nunca se dará por finda) do pensamento e das outras múltiplas linguagens que este consegue desencadear: adquiram estas linguagens o léxico e a gramática do discurso jurídico, a retórica da acção política e, por fim, a sonoridade própria da vida (quando esta começa a ser perspectivada, a partir de uma outra, subterrânea, modernidade, proposta pelo Romantismo, como a própria substância estética da existência). Contudo, o problema, hoje, deve formular-se de modo diferente porque se suspeita que a perspectiva da conquista e da manutenção do poder é o mais consistente horizonte da actuação dos intelectuais que, cada vez mais, são pensadores profissionais, naquela asserção funcional e funcionária, e talvez não muito respeitável, que Kant sustentava sobre os seus (ím)pares.

Seja este dado que explique como, ao longo do século $X X$, a rebelião dos intelectuais se suscitou também contra o achatamento, a massificação

(8) Veja-se Hugh Thomas, La guerra civil española, Barcelona, Grijalbo Montadori, 1995, II vol., pp. 546-550.

(9) Pierre Bourdieu, O poder simbólico, Lisboa, Difel, 1989, pp. 59 e 61.

(10) Cf., em sentido extensivo, Roger Chartier, Espacio publico, crítica y desacralización en el siglo XVIII. Las orígenes culturales da la revolución francesa, Barcelona, Gedisa, 1995, p. 192. 
do seu munus, a perspectiva de desaparecimento das suas prerrogativas, embora muitos tenham tido a percepção de que o seu "papel" social (numa nova linguagem da catarsis da consciência dramática, que a modernidade instaurou sobre o palco da história, induzindo em cena os seus humanos actores $\left.{ }^{(11)}\right)$ se jogava também na denúncia dos constrangimentos sociais, ou da ordem mundial, como presentemente ocorre, que não permitem a descoberta da fronteira possível da libertas que é o fundamento primeiro e, talvez, o último fim, de toda a paideia, como horizonte de expectativas e de toda a verdadeira actuação, nem sacrificial, nem emulatória, dos intelectuais. Entretanto, substanciais mudanças ocorreram: hoje, a religião não é mais, como no tempo de Marx, o ópio do povo; agora é o ópio que é a religião do povo (ou outras alquimias, transmutações). E, num certo sentido, também se massificou o vedetismo, e na hodierna superabundância de produção universitária e académica já é mais difícil encontrar, por estar tão disseminado, ou liquefeito, o ópio dos intelectuais de que falava depreciativamente Raymond Aron, porque a última revolução não se encontra em lado algum, em cabeça nenhuma. Por isso, assistimos actualmente a um duplo movimento cuja convergência se anuncia, embora de forma imprecisa e caótica: à medida que o munus suum se banaliza, também se massifica o perfil do intelectual, consumível, num mundo em que quase toda a gente será (pelo menos, no hemisfério norte), queira ou não queira, mais cedo ou mais tarde, qualquer coisa como aprendiz, auxiliar, oficial, sósia (clone) ou -intelectual propriamente dito.

É, portanto, sobre essas relações ambíguas entre os intelectuais (a elite, a massa crítica dirigente) e o poder, e, noutra perspectiva, sobre a relação ideada entre a própria elite e as massas, que analisarei alguns fragmentos do discurso integralista, sob a forma de três teses, sobretudo lidas à luz do paradigma reaccionário e de uma ilusão ucrónica que, como se procurará demonstrar, constitui uma das características mais marcantes deste pensamento totalizante.

(11) Fernando Catroga, Caminhos do fim da história, Coimbra, Quarteto, 2003, pp. 107-113. 


\section{O mundo está doente (sobre a decadência)}

O Integralismo Lusitano inscreve-se numa estrutura intelectual do pensamento europeu que reclama a antiutopia (entendida como um segmento de uma prática política, e como um combate cultural $\left.{ }^{(12)}\right)$, e partilha da diagnose do chamado decadentismo ocidental, que é típica das três primeiras décadas do século $\mathrm{XX}$, ao mesmo tempo que, contraditoriamente, se insere, numa certa perspectiva, na própria ideologia da decadência ${ }^{(13)}$, tal como a definiu Zeev Sternhell. De certo modo, como recentemente foi posto em evidência de modo sistemático, toda a cultura ocidental de matriz judaico-cristã, se reclama da filosofia do precipício e da queda no abismo, tomando ou não explícita consciência disso, pois exprime a angústia histórica da existência dolentis situada entre dois momentos cronologicamente distendidos, o da perfectível Génese, cujo registo se plasmou, por escrito, na sacralização do momento criador, e o da Salvação, cujo eco advirá dos confins de uma futura noite dos tempos, ou no triunfo do "Reino do espírito"(14). Mais do que esse registo, digamos, antropológico, o integralismo pensa-se como um movimento político de ideias, antiutopista e antipessimista, e partilha da opinião daqueles - Bergson, Hulme, Sorel - que vêm na crise do liberalismo e na difícil transição para a sociedade de massas, entendida como a passagem da sociedade representativa para a sociedade técnica de massas ou para a burocracia (Mosca, Pareto, Max Weber), os próprios sintomas de uma verdadeira crise da civilização ocidental.

Para melhor se compreender essa asserção temos de a contextualizar na emergência de uma cultura europeia novecentista. De certo modo, este antiutopismo prenuncia, ou acompanha cronologicamente, a crítica à democracia e à decadência do ocidente, que muitos dos movimentos de intelectuais, mesmo em campos antagónicos, denunciam. Com efeito, a eclosão da I Guerra mundial, e as terríveis consequências que ela trouxe para a Europa, foi assumida pelos intelectuais - pelo menos, os mais representativos - como a catarsis de uma crise dramática que atingia as

(12) Cf. Paulo Archer, Sentido(s) da utopia, Tomar, O Contador de Histórias, Colecção Húmus, 2002, pp. 40-47.

(13) Zeev Sternhell (org.), O eterno retorno. Contra a democracia a ideologia da decadência, Lisboa, Editorial Bizâncio, 1999, pp. 22-23.

${ }^{(14)}$ Cf. Fernando Catroga, Caminhos do fim da história, op. cit., pp. 26-36. 
estruturas tradicionalmente optimistas do pensamento europeu; isto permitiu a redescoberta daquela consciência simultaneamente vazia (ou opaca) e corrosiva de Nietzsche - Oh sancta simplicitas, dirá o filósofo dos esbocetos de uma cultura linear, redutível e dedutível, algébrica ${ }^{(15)}$ redescoberta, portanto, dessa crítica poderosa ao racionalismo iluminista e à divinização absoluta do "objectivo", e à comprovação urbi et orbi dos relativos dados da ciência (também do pensamento perfectibilista), crítica no limite da demolição ao cientismo e à religião do progresso, numa palavra, à filosofia das Luzes, que apenas soubera produzir uma moral utilitária, típica da moral dos escravos ${ }^{(16)}$.

Nem se diga que esta denúncia da decadência é apanágio, apenas, da direita ultra-reaccionária ou ultramontana. Nos diversos campos dos intelectuais, mas sobretudo na área do pensamento católico e cristão, e em certa tradição liberal e mesmo democrática, ganhou corpo a percepção de uma decadência ocidental iminente e catastrófica. Alguns reagiram avançando a proposta de um "pacifismo cristão" antevisto no cerne de uma ampla comunidade cristã que não seria exclusivamente intelectual mas que se destinaria a iluminar as massas de modo a que estas se pudessem desviar dos caminhos que rapidamente conduziriam ao massacre generalizado. Foi este o caso de T. S. Eliot que, já em 1939, tentava recuperar do deserto e do terrífico mar da tranquilidade lunar em que naufragara com o ciclo poético de The waste land (um mundo desértico impossivelmente habitado por transfigurações e espectros), superando o espírito da lost generation, na qual compartilhara com James Joyce, Lawrence, Hemingway ou mesmo com Gide, a perca da confiança no progresso indefinido e a dupla descrença nos deuses totalitários e nos totens salvíficos que se anunciavam ${ }^{(17)}$, melodiosos, nos amanhãs que cantam. E esta superação consistia na emergência de uma organização social cristã, simultaneamente longe do "quadro idílico da paróquia rural"(18) e da complexa rede das sociabilidades urbanas que se entreteciam nas grandes

${ }^{(15)}$ Cf. Friedrich Nietzsche, Cap. II, Sura 24., Para além do bem e do mal, Obras Escolhidas, vol. V, Lisboa, Relógio d'Água, 1999, pp. 39-40.

(16) Zeev Sternhell (org.), O eterno retorno. Contra a democracia a ideologia da decadência, ob. cit., p. 15.

${ }^{17} \mathrm{Cf}$. T. S. Eliot The idea of a christian society, 1939. Incluído na edição portuguesa dos Ensaios escolhidos, Lisboa, Cotovia, 1992, p. 89 ss.

${ }^{(18)}$ Idem, ibidem, p. 93. 
metrópoles, naquelas "cidades tentaculares", de que falavam os Poetas ${ }^{(19)}$ e nas quais se espelhavam as contradições - e as exclusões - mais profundas da sociedade burguesa.

Ora, Eliot não constituía um caso isolado nesse desiderato de superação da sociedade fáustica, pois Hilaire Belloc ou Chesterton aspiravam já à restauração de um catolicismo integral contra os devaneios "materialistas" do anglicanismo. Por sua vez, Jacques Maritain afastava-se, ainda na década de vinte, do nacionalismo integral da Action française (movimento entretanto excomungado e cujos intelectuais e obras foram colocados no Index prohibitorum, em 1926, pelo Papa Pio XI, a pretexto do confesso agnosticismo do patriarca dos reaccionários franceses, Charles Maurras) - e inflectia na direcção de um humanismo integral, que será, como se sabe, a base do chamado personalismo cristão que, como pensamento político sistémico e como cartilha social se desenvolveria já no post-II guerra mundial. Mesmo noutras esferas do pensamento teológico, nomeadamente por parte dos teólogos protestantes, "neocalvinistas" ou "neoluteranos", como Karl Barth ou Emil Brunner, propugnava-se por um retorno a uma ortodoxia da vivência cristã, convertendo-se essa metodologia neoevangélica, diga-se assim, naquilo que um historiador das ideias chamou, referindo-se especificamente ao próprio Barth, e ao seu célebre comentário à Epístola aos Romanos (1919), a teologia da crise ${ }^{(20)}$, ou uma espécie de cristologia finalista ou teleológica, cuja leitura política e social era claramente apocalíptica e, porventura, passível de uma leitura reaccionária, mesmo em termos do imediatismo político e das lutas sociais, ou da sua imobilização, a que inevitavelmente conduziria.

Estas visões salvíficas - pois sobre as perspectivas aterradoras do presente se lançava a esperança catalítica das "dinâmicas" sociais, como então se escrevia -, não conseguiam esconder um pessimismo latente que se tinha instaurado na intelectualidade europeia, e cujo texto paradigmático é mesmo Der untergang des abendlandes (1918-1922) de Spengler, e a sua percepção catastrófica da síncope do presente histórico, pois a ascensão

(19) A referência é ao poeta simbolista belga, Émile Veaharean (1855-1916) e ao seu célebre poema, o primeiro da trilogia dos Poèmes, editado em 1895, Les villes tentaculaires, denúncia do absurdo polvo ardente que lentamente estrangula os cidadãos.

(20) Roland N. Stromberg, Historia intelectual europea desde 1789, Madrid, Debate, Pensamiento, 1995, p. 347. 
das massas é, para Spengler, correlativa do declínio das elites e do princípio da autoridade ${ }^{(21)}$, e este facto só poderia ser remível pelo reencontro com o corpo da história longamente exilado no passado ${ }^{(22)}$. Também Nicolas Berdiaeff, um russo refugiado em França desavindo com a experiência soviética, nessa Paris mítica onde se reúnem, também, muitos dos expatriados norte-americanos, publica Un nouveau Moyen-Age (espécie de renascimento cristão) e o filósofo ibérico Ortega y Gasset, que continua hoje a exigir releituras, dava à estampa, em 1930, La rebelión de las masas, documento de denúncia de uma sociedade que posterga o indivíduo para o aniquilar em nome de ninguém, ou em nome da barbárie emergente, na qual ele passa a ser um mero "invasor vertical"(23), e de denúncia da decadência que decorre da própria noção de vacuidade. Noutro texto só difundido em 1938 mas parcialmente estabelecido entre 1921 e 1922, Ortega y Gasset tenta ainda profetizar o futuro, um pouco à maneira de Toynbee, ou, pelo menos, utilizando a matriz darwinista do desafio-resposta, partindo de um conceito de história como "puro pensamento" que, subtil, emerge do presente ${ }^{(24)}$ - algo que seria reflexo não já da astúcia da Razão mas de uma espécie da astúcia da História -e, paradoxalmente, acabará por confiar no "vaso mágico"(25) da ciência, num misto de comtismo assistémico e de idealismo naïf, a que não é estranha a concepção hierarquizante do evolucionismo neodarwinista, que não deixa de se reflectir numa espécie de organicismo social, embora bem diverso das mediações que o organicismo receberá quer do pensamento católico quer do fascismo ${ }^{(26)}$.

(21) Vide Gilbert Merlio, "A crítica da democracia liberal em Oswald Spengler", in Zeev Sternhell (org.), O eterno retorno. Contra a democracia a ideologia da decadência, ob. cit., p. 126.

${ }^{(22)}$ Oswald Spengler, La decadencia de occidente, vol. I, Madrid, Espasa-Calpe, $13^{a}$ ed., 1983, cf. p. 496 ss.

${ }^{(23)}$ Ortega y Gasset, La rebelión de las masas, Madrid, Rev. Occidente en Alianza Editorial, $8^{\text {a }}$ ed., 1990, pp. 109-110.

${ }^{(24)}$ Idem, El tema de nuestro tiempo, Buenos Aires, Espasa-Calpe, $5^{a}$ ed., 1945, pp. 26-27.

(25) Idem, ibidem, p. 27.

(26) Veja-se o curioso ensaio dedicado às "previsões darwinistas", em diversa perspectiva daquela que mantemos: Daniel J. Boorstin, $O$ nariz de Cleópatra. Ensaios sobre o inesperado, Lisboa, Gradiva, 1995, pp. 147-162. 
Dir-se-ia que a perturbação pessimista - originada no século XIX na filosofia de Schopenhauer, de Eduard von Hartmann ou de Nietzsche, e na temática da decadência de Jacob Burckardt - atingia áreas mais vastas da intelectualidade europeia: embora alguns mantivessem um optimismo moderado, começa a generalizar-se o tema. Paul Valéry, anunciara, em 1919, a precaridade da autoapregoada "civilização europeia" e anseia por uma "política do espírito"(27) que seja criada a partir da ideia de ditadura ${ }^{(28)}$, enquanto Luigi Einaudi descrevia no periódico Corriere della Sera os sintomas sombrios do declínio europeu; também Karl Jaspers, na esteira de duas obras, a este título, reconhecidamente importantes de Sigmund Freud, O futuro de uma ilusão e $\mathrm{O}$ mal-estar na civilização (Das unbehagen in der Kultur), escreve O espírito europeu e mais tarde, em 1931, dava à estampa $A$ situação espiritual da nossa época: trata-se de um conjunto de textos que não deixam de apelar à mitologia rousseauniana do bom selvagem, a este título reactualizada por Sigmund Freud - e, depois, teoria cara aos antropólogos, como Claude Lévy-Strauss, e tão característica da própria mitologia marxista, ao afirmar a inevitabilidade de alhures, certamente no passado (Morgan, Engels), ter existido um qualquer momento fundador e pleno da felicidade humana ${ }^{(29)}$. Tudo isto se passa como se o grau zero da civilização, qual paradisus in terram, fosse o momento inaugural, pre-adâmico, do esplendor humano e, uma vez cumprida a elipse, se voltaria a encontrar esse paraíso, quando do reino da necessidade se entrasse no repartido reino da pura evasão e da fruição, isto é, da liberdade.

Seja esta expressão grau zero da civilização tomada, quer no sentido histórico quer, com maior rigor, no seu sentido ahistórico ou metahistórico. A questão, bem entendida por Freud, seria - ou sempre será - a de gerar uma capacidade de resposta cultural, de desenvolvimento do entendimento humano sobre a sua Natureza e sobre as suas sociedades,

(27) Como é sabido, Valéry chegará a prefaciar a edição francesa, em 1934, do livro de António Ferro, Salazar. O homem e a sua obra, que no ano anterior tinha saído em Lisboa na Empresa Nacional de Publicidade, e acabará por influenciar o próprio conceito da política do espírito utilizado pela máquina de propaganda instaurada por Ferro.

${ }^{(28)}$ Cf. Paul Valéry, Regards sur le monde actuel, Paris, Gallimard, 1945, pp. 75-85.

(29) Inter alii, Sigmund Freud, no capítulo $\mathrm{V}$ de $O$ mal-estar na civilização, Rio de Janeiro, Imago, 1997, pp. 63-73. 
que neutralize e supere os impulsos autodestrutivos da humanidade ${ }^{(30)}$, porque, precisamente, sendo heterodestrutivos, e impondo, como solução, a destruição do outro, ou a amputação física ou mental dos outros no mundo, afinal, recaem sempre esses impulsos autodestrutivos como uma lança cravada no coração do tempo daqueles que sobrevivem. Georges Sorel, com a sua teoria sobre a violência revolucionária sindicalista das massas e o anarquismo redentor do fin-de-siècle, pareciam ser os alvos privilegiados de Freud. No centro de todas estas preocupações dos intelectuais centravam-se as massas, cujo carácter "caótico, "irracional" - a propensão para o instintivo e o inconsciente - estavam a ser equacionados no momento em que aparecem os iniciais estudos freudianos: em As leis da imitação de Gabriel Tarde (1890), La coppia criminale de S. Sighele (1893) ou Introduction of psychology de Mcdougall, se confirmavam também as conclusões que Gustave Le Bon sintetizou em La psychologie des foules (1895): "a substituição da acção inconsciente das massas pela actividade consciente do indivíduo é uma das principais características da época presente"(31).

Julien Benda, entretanto, tinha reeditado uma nova querela dos universais, agora a propósito dos intelectuais e do seu papel nas sociedades contemporâneas, e se a sua Trahison des clercs (1927) era vista como um mero profetismo israelita (típica tirada de um pensamento anti-semita que não perdoara a aparição de Belphégor, em 1919), ela suscitou uma nova velha questão: corporativos, atentos aos mealheiros, alguns perguntavam, como Thibaudet, se deveriam, ou não, os intelectuais pregar nos desertos e simplesmente alimentar-se "de gafanhotos e de mel selvagem" "(32). De resto, um pequeno batalhão de autores, mais ou menos consagrados nos areópagos ilustrados ou simplesmente instalados no modismo bem pensante, tinha erigido o tema da decadência ocidental como autêntica estrutura intelectiva e apelava à mediação compreensiva de um presente que anunciava já os sintomas do seu potencial apocalíptico: de Henri Massis (La défense de l'occident, 1927), ou de André Malraux (La tentation de l'occident, 1926) a Drieu de La Rochelle (num panfleto pró-fascista

(30) Idem, ibidem, pp. 111-112.

(31) Apud Franklin L. Baumer, O pensamento europeu moderno, vol. II, Lisboa, Edições 70, 1990, pp. 150.

(32) Citado por Michel Winock, in O século dos intelectuais, Lisboa, Terramar, 2000, p. 207. 
O jovem europeu) e a Huizinga que publicará, em 1928, A crise da civilização - texto comprometedor perante os olhares dos historiadores seus contemporâneos, sobretudo aqueles que começam brilhar no céu frentista da nova conjuntura intelectual instalada por volta da II Guerra mundial, mas que não faz esquecer a grandeza de rigor e de fascínio que legitimará esse movimento fecundo da historiografia europeia das mentalidades e que é $O$ declínio da Idade Média (1919).

É sabido como o pessimismo cultural foi sobretudo usado como bandeira da direita e da extrema-direita, e por ela manietado com evidentes propósitos políticos. Mesclado, em estratificações diferenciadas, de teorias antropo-racistas ou inegualitárias (Fourier, Vacher de Lapouge, Drumont, Fichte, Herder, Gobineau, Taine, Stuart Chamberlain), enquadrado pelo transformismo e evolucionismo (Darwin, Lamarck) socialmente relidos ${ }^{(33)}$, de índole positivista (Comte) ou empirista (Spencer), o pessimismo serviu de horizonte de combate no catálogo de uma nova kulturkampf que defendia, já não o carácter eterno da liberdade de pensar e de dizer, mas sim as verdades da raça, determinadas e originadas pela raça, em nome da ciência do futuro e de um ideal purificador e puritanizador da existência (como se a vida fosse apenas um somatório de processos biológicos e o pensamento não mais do que uma redução química). Na Alemanha, algumas das cátedras universitárias mais prestigiadas, em plena República de Weimar, transformam-se em tribunas anti-democráticas e plenas de anti-semitismo: denuncia um jornal da época, que um filólogo consagrado e presidente da Academia Prussiana das Ciências, Gustav Roëthe, começava, de ordinário, as suas aulas deste modo: "Nós que somos governados por judeus e proletários..."(34). Mais tarde, no início dos anos 40 , é visível como esse pessimismo estrutural se tinha convertido já na pura alienação do papel do intelectual - que, de resto, Benda já denunciara - como é o caso paradigmático de um Ezra Pound, que chegará a sustentar a Guerra na perspectiva da "milenária" luta

${ }^{(33)}$ Cf. Zeev Sternehll, "A função política e cultural do racismo", Michel Wieviorka (org.), Racismo e modernidade, Lisboa, Bertrand, 1995, pp. 55-61.

(34) Die Weltbühne, de 26 de Agosto de 1920, cit. por Dominique Bourel, "Os mandarins contra a democracia", in AA.VV., Berlim, 1919-1933. Gigantismo, crise social e vanguarda: a encarnação extrema da modernidade, Lisboa, Terramar (colecção Memórias), 2000, p. 140. 
contra a "usurocracia"(35); ou, queiramos ou não, de Martin Heidegger que, preso num galho, na Universidade de Friburg, do qual podia assistir, bem no meio, ao espectáculo devorador do precipício nazi, considera, em pleno Verão de 1942, a mundialização da guerra como a tentativa de extermínio da Europa, a pátria originária do Ocidente ${ }^{(36)}$, agressão oriunda do mundo anglo-saxónico e do "americanismo": a entrada da América na guerra é vista não como uma entrada "triunfal" na história mas, pelo contrário, como a entrada na autodestruição ${ }^{(37)}$, ou seja, espécie de ante-estreia da antihistória. A Europa e o Mundo, na diagnose destes intelectuais, já assistiam ao Apocalipse, pelo que bradavam eles pela redenção, confrontados com um mundo materialista no qual o optimismo e o perfeccionismo se encontravam estrangulados ${ }^{(38)}$. $E$ também noutro campo dos intelectuais, como se sabe, a alienação do seu papel crítico, parecia definitivamente questionada, com o engagement: essa alienação pode ser ilustrada por uma plêiade da intelligentsia europeia e americana, configurada pela lost generation, que se subordina ao mundo novo prometido pela III Internacional ou que, então, reivindica um autónomo "combate pela História" (como aconteceu com Bloch, um mártir da liberdade); ou que, de qualquer modo, acredita na capacidade revolucionária do realismo socialista (Brecht, Lorca, Romain Rolland, Aragon) como o chamado motor (numa altura em que as metáforas dos intelectuais eram tão mecânicas como as análises que produziam e das revoluções se dizia ainda avançarem $a$ todo o vapor) da transformação do mundo e da vida ${ }^{(39)}$, de criação idealizada do futuro ${ }^{(40)}$.

(35) Ezra Pound, L'America, Roosevelt e la cause della Guerra presente, s.l. (Saló), Edizioni Populari, 1944, p. 3.

(36) Martin Heidegger, Hölderlins <Der Ister>, trecho transcrito por Jeffrey Andrew Barash, in Heidegger et son siècle. Temps de l'être, temps de l'histoire, Paris, PUF (Pratiques Théoriques), 1995, p. 169.

(37) Idem, ibidem.

(38) Para uma relação do integralismo com a ideologia da decadência, cf. Paulo Archer de Carvalho, "De Sardinha a Salazar. O nacionalismo entre a euforia mítica e a formidável paranóia", Revista de História das Ideias, Coimbra, vol. 17, 1995, pp. 79-123, sobretudo o ponto 4., "Do paraíso perdido à decadência do Ocidente", pp. 92-100.

(39) Veja-se, em Portugal, uma apaixonada recepção dalguns destes autores (sobretudo Rolland e Lorca), e do sentido de historicidade no combate cultural, por parte de um dos primeiros intelectuais neo-realistas, o poeta e ensaísta, 
Ora, de certa maneira, o Integralismo foi inteiramente contemporâneo desta vaga de inquietação intelectual que atravessava a Europa. Em primeiro lugar, diga-se, estruturou-se como um movimento de intelectuais, muito jovens, congregados geracionalmente na casa dos 20 ou 25 anos, que esconjuravam a democracia, o princípio da representação liberal, as constitucionais liberdades, e o acervo de tópicos e de referências bibliográficas que começam a acartar é muito amplo - antes de serem propriamente integralistas, são esotéricos, simbolistas, mais da fina veia de salão, à Eugénio de Castro, ou naturalistas (Monsaraz) do que da inspiração distanciada, a jorros, de Nobre, nefelibatas da segunda geração, vagamente republicanos, ou anarquistas, leitores de Proudhon e de Sorel, de Bourget. Neste quadro (e temos de voltar sempre a este ponto porque algumas leituras actuais repetem, em tese geral, a perspectiva de Raul Proença, ele próprio um écrivain politique ${ }^{(41)}$ e não um historiador), dizer que o integralismo foi, apenas, no seu conjunto, uma importação da Action française, é redutor ${ }^{(42)}$, pois se é certo que o movimento do pelicano partilhou o caminho europeu com os movimentos antidemocráticos, antirepublicanos, anticomunistas, ou com o próprio positivismo reaccionário, é igualmente verdadeiro que o integralismo tentou estabelecer uma síntese com o hiper-tradicionalismo que deixara caminho nalgum do pensamento político português da transição dos séculos XVIII a XIX (marquês de Penalva, Furtado de Mendonça), ou da primeira metade do

coimbrão e figueirense, de Alter do Chão, in Joaquim Namorado, Obras, vol. I, Uma poética da cultura, Lisboa, Caminho, 1994 (colectânea de textos e ensaios org. e prefaciada por António Pedro Pita), v. g., pp. 79-107 ou 130-137.

(40) Maria Manuela Tavares Ribeiro, "A Europa dos intelectuais nos alvores do século XX. A Europà em crise e a idealização do futuro", Estudos do Século XX, Coimbra, n. ${ }^{\circ}$ 2, 2002, pp. 109-133.

(41) Apud António Reis, Raul Proença. Biografia de um intelectual político republicano, Lisboa, Ed. do Autor, t. II, 2000, pp. 558-559 (policopiado).

${ }^{(42)}$ Não vamos aqui debater o sentido e o alcance da polémica traçada com a Seara Nova e, nomeadamente, com Raul Proença, pois já foram objecto da nossa análise em estudos anteriores. Cf. Paulo Archer de Carvalho, Nação e nacionalismo. Mitemas do Integralismo Lusitano, Coimbra, Faculdade de Letras, pol., 1993, pp. 96-102; idem, "Da Nação Portuguesa (1914-1938) ao Integralismo Lusitano (1932-34). A insurreição dos intelectuais", in Revistas - ideias e doutrinas. Leituras do pensamento contemporâneo, Lisboa, Presença, 2003, pp. 142-143 e 151. 
século XIX, na linha de certa teorização do reaccionarismo miguelino ${ }^{(43)}$ (Faustino José da Madre de Deus, Frei Fortunato de S. Boaventura; José Agostinho de Macedo, José Acúrsio das Neves, Ribeiro Saraiva e, sobre todos, José da Gama e Castro e o seu $O$ novo príncipe ou o espirito dos governos monárquicos) e até, com alguma da produção do positivismo teofiliano. E mais: desconhece, porque Proença também desconheceu, a fase constitutiva (na proposição de Ricoeur), mais homogénea e criativa, do integralismo - a tese dualista do hispanismo, como iremos ver.

Mas são detectáveis outros elementos desse sincretismo ideológico: intelectuais que, em certa altura do percurso reaccionário, se situaram na área do integralismo ou esconjuram a "torre de marfim dos decadentes franceses" (o satanismo ou a iconologia do poeta maldito, de Verlaine a Rimbaud e de Mallarmé a Baudelaire), nessa época de indecisão activa ${ }^{(44)}$, ou, então, numa fase mais elaborada, apelam mesmo contra aquele intelectualismo a que Lange chamou o "excesso do princípio da inteligência", pois a inquietação espiritualista e a impersonalidade, ou o despojamento do eu egotista de que falava Antero de Quental, prenunciam, para António Sardinha, um novo estádio na espiritualização dos intelectuais, que deveriam retornar, novos clercs, à cruzada contra a impiedade, a descrença e a secularização das consciências (que são entendidas como um problema mental da sociedade que só encontrará solução política, uma

(43) Sobre a problemática da existência de uma verdadeira e autónoma estrutura ideológica no miguelismo - questão muito importante para a própria análise e discussão dos fundamentos e dos segmentos ideológicos tradicionalistas que funcionam no interior do discurso integralista - veja-se I parte da obra, bem documentada, de Armando Malheiro da Silva, Miguelismo. Ideologia e mito, Coimbra, Minerva, 1993, pp. 5-218.

(44) Em carta não datada, provavelmente escrita nos finais de 1917, enviada por Alfredo Pimenta a Silva Gaio, e que constitui um importante manifesto de Pimenta contra a chamada "estética metafísica", o intelectual nortenho, na altura a descrever uma trajectória de aproximação ao Integralismo, que irá interromper definitivamente em 1923 com a formação da Acção Realista, apela por uma "filosofia positiva", que permita articular conhecimento e intuição, subalternizando a arte (mera emanação emocional da inteligência) em função da ciência. Cf. "Correspondência de António Sardinha, Luís de Almeida Braga, Alberto Monsaraz, Alfredo Pimenta e Hipólito Raposo para Manuel da Silva Gaio", int. e transcrição de Maria de Fátima Correia de Carvalho, in Arquivo Coimbrão, vol. XXXI-XXXII, 1988-89, pp. 92-94. 
vez promovida prévia batalha intelectual). $O$ incontestado líder do campo integral procurou, como se sabe, legitimar a sua insurreição a partir da exemplaridade da geração de setenta, maxime do próprio paradigma anteriano, e ao poeta reivindicou-o como um mestre precursor (como, com certeira razão, até Teófilo fizera ascender um fio da teia do pensamento contra-revolucionário, ao ler, justamente, na estratégia hipernacionalista e unitarista que o republicanismo assumira, uma confessa metodologia ordeirista, relevante ao nível da análise do conservadorismo social que o positivismo na versão teofiliana se revestia, e que se encontra plasmado em muitas das suas páginas). Ora, uma vez subsumido o eu nessa espécie de novo organon social, uma vez dissolvido o chamado capitalismo judaico-protestante - o próprio "espírito do capitalismo", recolhendo a tese de Werner Sombart, só estaria capacitado a produzir a "metalização social"(45) e estaria contaminado pela ética protestante, naturalista e pagã, para cujos fundamentos o próprio hebraísmo teria contribuído (M. Weber) ${ }^{(46)}$-, criar-se-iam, assim, as condições indispensáveis para a irrupção de uma nova era caracterizada pela espiritualização do ser $^{(47)}$.

Mais: se o evolucionismo e o cientismo, nos finais do século XIX, tinham reforçado a ideia de que a evolução, e o progresso, em particular, estavam condenados, nas suas leituras políticas, à generalização da ideia de que se atingiria um "estado uniforme de que a liberdade completa será a lei" (G. Valois) então demonstrava-se que progresso e evolução só poderiam desembocar na democracia. A refutação do discurso cientista encontrou-a Sardinha em Les sélections sociales de Vacher de Lapouge. Aí se tenta demonstrar como as ciências, da química à física, da geologia à paleontologia, embrulhadas no "sentimentalismo sonhador da geração passada" à medida que novos dados científicos se tornariam mais precisos, acabariam por revelar "o abismo inevitável - o nada"(48) ao qual a crença contemporânea na ciência conduzira. Para isso teria que se

${ }^{(45)}$ António Sardinha, Ao princípio era o Verbo. Ensaios E estudos, Lisboa, Livraria Portugália, 1924, p. XX.

(46) Idem, A aliança peninsular, 3. a ed., Lisboa, Biblioteca do pensamento político, 1972, p. 279.

(47) Idem, "O Verdadeiro Antero", Ao princípio era o Verbo, ob. cit., pp. 98-105.

(48) Idem, "Ciência e Democracia", Na feira dos mitos, 2." ed., Lisboa, Edições Gama, 1942, pp. 201-207. 
proceder, primeiro, à destruição da democracia, "estado inorgânico de uma sociedade primária", contrário à "especialização crescente" a que a "competência obriga", como Sardinha lera em René Quinton ${ }^{(49)}$. O processo instrutório e método de destruição da democracia parece terem sido longamente estudados em Georges Sorel, por via de Maurras. Como foi correctamente anotado ${ }^{(50)}$, Sorel seguira a tese da evolução criadora de Bergson (relida por Gustave Le Bon, segundo o qual da "volatilização da matéria" se criaria energia e "espírito"; e também a liquidação do ponto de vista objectivo do idealismo alemão, ao qual Schopenhauer contrapusera as ideias de representação e vontad $\left.e^{(51)}\right)$, para quem o intelecto e as faculdades mentais, a inteligência, apareciam já não como uma evolução puramente orgânica, resposta de sentido utilitário e pragmático ao meio biológico da vida, como o cientismo pressupunha, mas como elementos escravos de uma "força vital", impulso cósmico racionalmente não determinado (como a vontade em Schopenhauer e o Inconsciente em Hartmann), força por sua natureza obscura, e, por isso, não racionalmente descodificável mas apenas apreensível pela intuição. Ora, em Réflexions sur la violence (1908), Sorel, que descrera já das ilusões do progresso e abjurara a democracia, os sistemas representativos como expressão da vontade geral, transforma a "força vital" de Bergson em elemento que desencadearia a luta de classes, não no quadro hegeliano duma lógica universal da história, nem no quadro marxista de uma predeterminação involuntária das forças sociais, mas no quadro da "violência criadora" do proletariado, isto é, da acção das massas no interior do sindicalismo revolucionário. Daí que, como essencial mito revolucionário, capaz de dar expressão e unificar esse momento de ruptura da sociedade burguesa (como outrora ocorrera com o cristianismo que se constituíra num mito unificador) e fabricada por uma filosofia social, a violência das massas, que seria expressão de uma espontânea "apaixonada intensidade" da

(49) Idem, ibidem, p. 205.

${ }^{(50)}$ George H. Sabine, A history of political theory, trad. port., História das teorias políticas, vol. II, S. Paulo, Editora Fundo de Cultura, 1964, pp. 850-858. Veja-se, também, Franklin L. Baumer, O pensamento europeu moderno, vol. II, ob. cit., pp. 153-158. Sobre Maurras, Jean-Luc Chabot, Le nationalisme, Paris, P.U.F., 1988, pp. 59-66.

(51) Cf. A. Schopenhauer, Algunos opúsculos, Madrid, Editorial Reus, 1921, Cap. II $\S 27 .^{\circ}$, p. 42 ss. 
convicção revolucionária ${ }^{(52)}$, através da greve geral, conseguiria destruir a cega astúcia do capitalismo. Sorel propunha a emergência dos mitos irracionais no sopé de um caminho ascensionalmente catártico que o movimento de massas haveria de cumprir, ao mesmo tempo que pretendia destruir os "dogmas burgueses" da representação política, da "ciência" histórica e do progresso indeterminado. Ora, se é certo que a filosofia social soreliana se encontra ainda numa fase distorciva da ideologia integral, ela implicou um trabalho de conversão integralista - daí a sua hesitação epistemológica - que fosse capacitada a recolocar o cristianismo como vértice de toda a mitologia unificadora da sua própria filosofia social. Quer isto dizer que, e uma vez concluído esse processo de recentração, foi abandonando o integralismo, depois de 1919, a retórica da violência das massas ${ }^{(53)}$ não abdicando, porém, como referência metodológica, do conceito de revolução social.

O particular interesse, sob a específica perspectiva da história intelectual (que é a história das ideias cruzada com a microhistória dos diversos campos dos intelectuais), que o estudo dos pressupostos integralistas acarreta, consiste no facto de nunca estes se terem convertido, in se e per se, e por própria mão, em poder político, mas sim num genuíno poder intelectual. Torna-se, assim, no momento privilegiado para reflectir sobre uma radical crítica à modernidade, partindo de alguns dos pressupostos que ela própria produziu, e sobre os quais assentava; ou seja, utilizando já a blindagem de um sistema crítico. Depois de acratas, sindicalistas, socialistas e niilistas terem vociferado sobre a sujeição humana a que a "liberdade burguesa" conduzira o proletariado, a própria existência (Nietzsche), a noção de decadência e a sua denúncia ressoava à crítica sistemática da sociedade burguesa que parecia brotar das pedras da calçada, oriunda do pensamento sindicalista revolucionário e do próprio movimento operário (Proudhon, Stirner, Sorel, Valois, Labriola, sub specie: Marx, Sombart) que se tinha lido e estudado do lado de fora da Porta Férrea, juntamente com o filósofo da Aporia, Friedrich Nietzsche, que conheceu nas letras portuguesas uma recepção muito mais intensa e, por vezes, mais atenta, mesmo em período cronologicamente anterior

(52) Cf. Paul Guilbert, Terrorismo, nacionalismo, pacificación, Madrid, Catedra, Teorema, 1998, p. 100.

(53) Paulo Archer, Nação e nacionalismo, ob. cit., pp. 102-106. 
à publicação da Águia, de Orpheu e da Seara Nova, do que até há poucos anos se supunha ${ }^{(54)}$ - cuja transmutação de valores de Para além do bem e do mal, ou o sentido desértico do Anticristo, ou a "morte de Deus" anunciada por Zaratustra, não poderiam passar para a fase constitutiva da ideologia integral. Enquanto a provocação de Nietzsche, o desprezo aristocrático pela vulgaridade ressentida ${ }^{(55)}$, sim, poderia ser entendido (talvez como episódio epígonal da revolta antiteísta) no quadro de um pensamento reaccionário e elitista - mas toda a face de uma obscura modernidade não se compreenderia, claro, como, a par de Kierkegaard, a Existenz seria o conceito inaugural e, contraditoriamente, um novo território metafísico e especulativo para o pensamento (Heidegger, Sartre). Crítica integralista da decadência que, estranhamente, se situava, oscilando (como o pêndulo de Foucault, sem nunca se decidir, porque a tal é impedido pelo movimento, a precipitar-se no seu ponto mais baixo) entre dois pólos antagónicos, diacrónica ou anacronicamente instalados entre uma mítica era pré-burguesa, à qual a lição historiográfica herculaniana não era estranha, e uma era post- "civilização material do capitalismo", para utilizar agora a expressão consagrada - e aqui tão necessária - de Fernand Braudel. Essa crítica prenunciava uma ruptura com a civilização burguesa, fáustica e inorgânica, atomista e materialista, como era caracterizada, em suma; e permitia sobredeterminar o projecto do pelicano como um movimento cuja direç̧ão apontava a uma "nova idade média" do futuro.

Por isso, meio século após Antero ter dado a conhecer a conferência-opúsculo Causas da decadência dos povos peninsulares (1871), vinha Sardinha refutar as teses do poeta, acusando-o de ter bebido em Alexandre Herculano (o que era certo) e em Henry Th. Buckle, tido como o teorizador racionalista da decadência peninsular, ao qual contrapunha, partindo da Pequena história de Inglaterra de Chesterton, que fora recentemente impressa em Espanha (1920), a ideia de que a Hispânia desenvolvera uma civilização superior à época da Invencível Armada, cuja afirmação de personalidade elevada ao extremo (mas não de alucinação, Nietzsche) produzira, simultaneamente, "as estâncias sonoras de Camões" e ateara

${ }^{(54)}$ Cf. Américo Enes Monteiro, A recepção de Friedrich Nietzsche na obra intelectual portuguesa (1892-1939), Porto, Lello Editores, 2000, p. ex., sobre o "apóstolo da violência", pp. 199-217. Infelizmente, é omissa a obra sobre a clara recepção da Nietzsche em Sardinha.

(55) Peter Sloterdijk, El desprecio de las masas, ob. cit., pp. 55-62. 
"uma indominável labareda mística no peito de D. Sebastião - cruzado póstumo" (56). Negando uma decadência congénita, pregando a amor do Absoluto e do dogma (Chesterton) e socorrendo-se de Moniz Barreto, afirmaria Sardinha a necessidade de criação de "um princípio superior" contra essa letargia inibidora do presente; e nos movimentos subterrâneos do nacionalismo europeu perscrutava já a hora em que "as portas do futuro se nos hão-de abrir com o estrépito dos triunfos antigos"(57).

De facto, tido como o áugure oitocentista dos destinos da pátria, o último senhor, como em verso celebra Sardinha a figura de D. Miguel ${ }^{(58)}$, o mártir da lenda negra ${ }^{(59)}$, ou por estar mais atento ao século XVII dos poderes pessoais do rei e do definhamento das cortes, ou por ser temporalmente impossível cumprir essa viagem pelo presente, não faria a menor ideia que coisa seria essa contemporaneidade dos inícios do século $\mathrm{XX}$ - do proletariado, do telefone, da luz eléctrica, das ilhas, das vilas lisboetas. Nem saberia como ler os auspícios no voo dos aviões. O próprio António Sardinha o iria reconhecer quando confirmava, comentando H. G. Wells e Maritain, a "encruzilhada sinistra" da posição teórica em que se encontrava o integralismo, tal Quixote disperso entre a loucura e a paixão, a loucura que se volve em paixão, note-se, pois eram os seus ideólogos, simultaneamente, "antimodernos" e "ultramodernos"(60).

Mas, perdida a tensão do movimento, cairia o pêndulo para o ponto mais baixo da sua trajectória imaginária, e o antimoderno da sinistra encruzilhada recalcou a pretensa ultramodernidade e com isso perdeu-se um ponto teórico de observação única, não apenas sobre as tensões ideológicas no interior do integralismo lusitano, mas sobre a difícil encruzilhada em que a própria sociedade portuguesa se encontrava quando se postava em direç̧ão à modernidade. Quebrado o ímpeto, veio o louvor, antigo, do santo ofício inquisitorial e da excelência da posição magestática, e o elogio de uma certa aurea mediocritas que passará como ideossincrasia fundamental para o salazarismo. Em toda a sua extensa produção, ensaística, poética, política, panfletária, como na de

(56) António Sardinha, A aliança peninsular, ob. cit., p. 290.

(57) Idem, ibidem, p. 295.

(58) Idem, Pequena casa lusitana, Porto, Livraria Civilização, 1938, do soneto inc. "A El-Rei D. Miguel", p. 165.

(59) Idem, Ao ritmo da ampulheta, Coimbra, Lumen, 1925, p.216.

${ }^{(60)}$ Idem, Ao princípio era o Verbo, p. XXI. 
alguns dos seus companheiros de armas e de letras, por vezes prolixos (Hipólito Raposo, Monsaraz, Ameal), Sardinha e o integralismo criaram instrumentos estéticos e dispositivos doutrinários que perderam qualquer leitura "ultramoderna", a despeito de autores como Freud, Weber e o próprio Sombart serem por ele pioneiramente referidos. Mais. O integralismo, não só se caracterizou pelo facto de ter sido constituído em movimento de intelectuais que abjuraram a Modernidade, como desconheceu a sua expressão crítica, e a sua dimensão estética e vivencial, "ultramoderna": ignorou, sequer, a essência ou as concepções instituintes da revolução modernista desencadeada por Pessoa ${ }^{(61)}$. Eis a razão pela qual, mesmo para estudar as lutas políticas e sociais no tempo da República, para não falar desses anos extraordinários de debate e irrupção cultural (1911-1927), é mais útil ler um poema de Pessoa, provavelmente de algum dos seus heterónimos (como Álvaro de Campos ou Bernardo Soares), do que um ensaio de António Sardinha. Se bem que, para entendermos o complexo pano de fundo da ideologia do Estado Novo, ou a sua estrutura organicista, o seu pensamento contra-revolucionário, a sua mitologia historiográfica, colonial e ecuménica, é indispensável estudar Sardinha que nele nunca viveu; e esquecer Pessoa, que, por vezes, parecia viver noutro mundo (Esse momento em que sossegadamente não cremos em nada, / Pagãos inocentes da decadência).

\section{Nosso, o mundo (Todo o poder aos intelectuais)}

O que se acabou de escrever permite-nos compreender como a estratégia discursiva do integralismo pretendia invalidar a intocabilidade com que os sacerdotes cívicos da República, e sua procissão de intelectuais laicos, de congressos de livre-pensamento, de círios civis e de reformas secularizadoras ${ }^{(62)}$, se supunham revestidos, e que estes tinham utilizado como estratégia de conviç̧ão desde, pelo menos, que as traduções e interpretações do positivismo iam chegando, e com elas a sua arquitectura sistémica "completa" $\mathrm{e}$ "fechada", através da qual se propunha uma

(61) Cf. P. Archer, "A Insurreição dos intelectuais", art. e loc. cit., p. 136 ss.

(62) Veja-se, de Fernando Catroga, "O livre-pensamento contra a Igreja. A evolução do anticlericalismo em Portugal (séculos XIX-XX)", Revista de História das Ideias, Coimbra, vol. 22, 2001, pp. 302-321e 338-354. 
explicação científica da Natureza, e das suas imensas extrapolações sociais, historiográficas e filosóficas. Quando o positivismo passou a ser um sistema ideológico dominante, no verdadeiro sentido do termo, como explicação totalizante do processo da vida e da existência no macrocosmos e no microcosmos, dominantes passaram a ser os intelectuais positivistas nos meios científicos, literários ou artísticos. Degenerescência e patologia social passaram a ter citações assíduas em artigos de revista e em tiradas de dramaturgos ou em motivo de narradores. Atingida a história e a filosofia, em termos epistemológicos, pela mesma apetência de exacta e empírica comprovação que constituía a essência do conhecimento científico-natural e científico-matemático, tinha o positivismo a enorme vantagem de ser uma linguagem clara e concisa, embora os conceitos fossem por vezes nublosos e áridos, integrada num sistema categorial que herdara muito do melhor sistematismo e do logicismo kantiano, em particular, e do simetrismo analítico próprio das Luzes, com as quais o positivismo, de resto, prolonga e compartilha a esperança da sapiente desocultação total de um desconhecido mundo.

Por isso, se compreende como o positivismo de direita era fundamental na cekonomia do discurso integral, pela objectividade e clareza da frase (impositiva, seca) dedutiva, pela actualização terminológica e, sobretudo, pela possibilidade que abria de invocação do novo deus, mestre absoluto do universo - a Ciência, a sociologia - e da convocação da sua sacerdotisa, oficiante contemporânea: a pítia razão científica, no momento em que a razão filosófica (ou teológica) parecia encontrar-se como S. Paulo, antes de cair do cavalo, perdida. A tarefa a que o integralismo se propôs, porém, era a de demonstrar como na mais antiga sabedoria, a das Escrituras, poderia radicar a mais moderna das argumentações, a das Ciências.

É este facto que permite explicar como, perdida a cena política, monárquica e clerical, no transcurso do século XIX, pelo debate intelectual, pelos jornais, pela pressão da opinião pública, pela secularização das consciências, pelo triunfo do republicanismo (e da sua mitologia nacionalista), e pela aceleração da dessacralização ou da deslocação da sacralidade, urgia agora ganhar terreno no campo da inteligentsia nacional, para se retomar, reconstruir, o poder, não como uma acto de "restauração" mais ou menos constitucional, mais ou menos cartista, mas como um facto político ex-novo, fabricador de uma nova realidade social, de uma nova legitimidade política (que não assentasse nem no sistema representativo demo-liberal, nem na ideia de sufrágio e de expressão 
política directa da opinião pública, contornando o voto e a liberdade de associação, de expressão e de pensamento) e de uma nova fundamentação filosófica, melhor, de uma nova argumentação para velhas conviç̧ões tomistas e organicistas, de conimbrigenses e de teorias aristotélicas que criavam a suspeição, desde a polis grega às heresias medievais, do maleficio da democracia. Era a primeira vez em quase um século, desde o triunfo definitivo do liberalismo, nas décadas de trinta e quarenta do século XIX (digamos, depois de 1834-1847), que as formações sociais mais conservadoras, com uma evidente hegemonia de terratenentes, encontravam uma expressão ideológica não-defensiva (sintomático do que se afirma está na maior preocupação da reorganização agrícola do que na produção industrial $\left.{ }^{(63)}\right)$. Mas, precisamente, porque se reivindicava $o$ Integralismo da vanguarda da comunidade, organicamente considerada, a partir de Oliveira Martins, e se reivindicavam as memórias primordiais da nação que, desde o síndroma comemoracionista, tinham sido as bandeiras mesmas do nacionalismo republicano, assumia-se o movimento do pelicano como uma ideologia de ofensiva (ou de contra-ofensiva) que esgrimia o slogan do positivismo maurrasiano - o célebre politique d'abord - não para impressionar le campagnard et l'abbé mas pour épater le bourgeois e disputar a opinião em solo urbano, e no seu próprio terreno cultural, ao empunharem as armas da explicação "científica" e da "positiva" experimentação política. Ora, na óptica do Integralismo, a tomada do poder político só faria sentido se fosse efectivamente precedida pela conquista de um novo poder intelectual, isto é, se no próprio interior dos fóruns do debate intelectual e do aggiornamento num programa ideológico, e por esta mesma via, fosse ganha a batalha das ideias e a luta pela razão histórica, ou melhor, por essa espécie de desrazão providencial da história, fio quebrado pela vontade sacrílega dos revolucionários da Bastilha, dos sanguinários jacobinos de Robespierre, e pelos apátridas anglos, da pérfida Albion, que degeneraram em americanos e capitalistas ${ }^{(64)}$,

${ }^{(63)}$ J. Pequito Rebelo, chegou a escrever um tratado de "lavoura alentejana", Novos métodos de cultura. O método integral, 2. ${ }^{a}$ ed., Lisboa, Ferin, 1919, onde refere o absentismo, a escassez de mão de obra e o "latrocínio" como os "males" que o método procurava curar (pp. 18-19). Não se conhece um correspondente "método integral" para a indústria.

(64) João Ameal, No limiar da idade-nova, Coimbra, Imprensa da Universidade, 1934, p. 91 ss. 
e pelos metecos (estrangeiros, estrangeirados, judeus) que pululavam na velha Lusitânia ${ }^{(65)}$.

Poderíamos regular o enfoque a algum pormenor, que nos elucidasse como foi do exterior das tradicionais instituições de ensino e da cultura que os integralistas procuraram pontos estratégicos no combate ideológico. Na procura de uma nova base de legitimidade intelectual, os integralistas utilizaram as vias usuais para a conquista do público leitor. Algumas dessas estratégias de conquista eram, no entanto, bem mais prosaicas do que se poderia pensar e passavam até pela inclusão naquelas escolas de elogio mútuo, ou de mediocridade acrítica, que já meio século antes Antero de Quental justamente denunciara na questão coimbrã, e que continuariam a perdurar, como fenómenos institucionais, na intelectualidade portuguesa. Com efeito, Alberto de Monsaraz, em carta datada de Março de 1916, numa época em que o Integralismo ainda não tinha uma real implantação, dirigindo-se a um amigo, o poeta e jurista Manuel da Silva Gaio, desmonta a rede completa de influências de que os intelectuais tradicionalistas dispunham nos órgãos da imprensa, de "crítica amiga", da qual poderia beneficiar também Gaio. Essa rede passava por Júlio Dantas, o patriarca do academismo, que então escrevia na Ilustração Portuguesa, por Garcia Pulido, o "nosso" crítico, como se refere ao articulista de $O \mathrm{Dia}$, por Augusto de Castro, que então dirigia a edição da noite de $O$ Século, década e meia antes de transformar o órgão histórico do republicanismo no órgão oficioso do Estado-Novo, por Lourenço Cayolla, crítico de arte e literatura no Diário de Notícias; na $L u t a$, órgão dos unionistas, só poderia contar com a crítica favorável de Forjaz de Sampaio se tivesse o poeta "uma boa cunha" para o jornalista; no entanto, continuava Monsaraz, "na Nação está o nosso amigo D. José Manuel de Noronha", e na Ordem poderia contar ele com o director, Carmona Saldanha. Eram estas, como confessava Monsaraz nessa carta, "as únicas cunhas capazes de vulgarizar" a obra do amigo ${ }^{(66)}$ e era esta a rede de emulação intelectual que os integralistas dispunham e utilizavam.

${ }^{(65)}$ Sobre algumas destas expressões veja-se, por exemplo, António Sardinha, "A ordem-nova", Ao princípio era o Verbo, ob. cit., p. 298 ss.

(66) Cf. Carta de 19 de Março de 1916, que continua a recepção do poema Chave Doirada de Silva Gaio, in "Correspondência de António Sardinha, Luís de Almeida Braga, Alberto Monsaraz, Alfredo Pimenta e Hipólito Raposo para Manuel da Silva Gaio", Arquivo Coimbrão, ob. cit., 1988-89, p. 88. 
Mas outros caminhos de conquista intelectual eram menos, ainda, espiritualmente ortodoxos, na perspectiva de quem assumia um raro status aristocrático e elitista, ligado tanto à retórica da "chã" ruralidade como, nalguns casos, à riqueza fundiária que alimentaria consecutivas edições de panfletos e de livros, de jornais e de revistas, importações em massa de livros, avaliando pelas listas de encomendas ${ }^{(67)}$. Em 1968, num estudo pioneiro, Hermínio Martins, chamou a atenção para um fenómeno cultural de grande relevância: o integralismo contém o apelo romântico à violência física (Maurras, Sorel), e essa violência encontra-se declaradamente assumida e integrada numa estratégia de "jacobinos da direita"(68), apesar de não constituírem os jovens integralistas propriamente a lumpenintelligenz, aquela espécie de subclasse de intelectuais de café e de arruaceiros profissionais de cervejarias, ou de paupérrimo proletariado artístico e literário, que enxameia a Europa no dealbar do século XX. Essa estratégia de imposição intelectual é pragmaticamente descrita num texto epistolar de Alberto de Monsaraz: "o Integralismo progride vertiginosamente", escreve ao mesmo amigo, Silva Gaio, em finais de 1917, "imagine que já temos a maioria da Faculdade de Direito de Lisboa. Vamos agora organizar os caceteiros e eu ponho muita esperança nesta forma de propaganda pelo facto"(69). E apesar de gradualmente submergida pelo magistrado místico do António Sardinha (1887-1925) dos últimos anos de vida, também uma retórica anti-semita, nele originada sem consequências práticas, aflora nalguns dos intelectuais da extrema-direita, e passará, por inteiro, para o nacional-sindicalismo ou para o delírio

${ }^{(67)}$ Aníbal Pinto de Castro (A Cidade, Revista Cultural de Portalegre, n. ${ }^{\circ}$ 2, especial António Sardinha, Portalegre, Jul.-Dez. 1988, pp. 33-36), publica extensas listas de pedidos de edições francesas ao editor e livreiro coimbrão França Amado, entre Março e Novembro de 1913: são cerca de oitenta obras de Sorel, Maurras e C. ${ }^{\text {te }}$ Léon de Montesquieu (colecções quase completas destes autores), de Barrès, Cochin, Valois, Maze-Sencier, Grémond, Pottecher, Comte de Chambord, Lucie, Faure-Guyau, Louis Bertrand, $M .^{\text {is }}$ de La Tour du Pin, Porodi, Fouillé, Poincaré, Le Bon, Lasserre, Paul Crouzet, Ch. Brun, Morselli, Agathon, Maigron, L. Daudet, Balzac, Natali, Cardaillac, Dimier, Gobineau, entre outros escritores (cristãos, conservadores e contra-revolucionários).

${ }^{(68)}$ Cf. Hermínio Martins, Classe, status e poder, Lisboa, Instituto de Ciências Sociais, 1998 , pp. 23-24.

${ }^{(69)}$ In "Correspondência...", ob. cit., carta de 3 de Novembro de 1917, ibidem, p. 91 (itálicos nossos). 
"modernista" e anti-semita de um Mário Saa, que exploram o que o Integralismo, globalmente considerado, em si reprimiu ou recalcou - o racismo.

O problema da conquista das elites intelectuais mantinha-se, portanto, complexo. Como arregimentar, convencer, argumentar, se os intelectuais integralistas estavam fora de cátedras e de academias e se estas eram tidas, prática rotineira, como fóruns de arregimentação, momento privilegiado para a sedução e para a "sedição" ideológica nos meios universitários do país? O caso de António Sardinha é exemplar: ocupara, concluído o curso de direito, um modesto lugar de oficial de Conservatória em Monforte, à data da sua definitiva conversão à causa monárquica e tradicionalista, que começou, publicamente, pelos inícios de 1912, embora haja anteriores registos de duras críticas, que em privado se zurziam, ao novo regime republicano. Alentejano, provindo duma middle-class pauperizada, do pequeno funcionalismo, com antigos ramos em árvore genealógica, foi grevista em Coimbra em 1907, adepto fervoroso do regicídio, chegara a anunciar, em plena hora da revolução republicana de 5 de Outubro de 1910, àquela que viria a ser sua mulher, D. Ana Júlia Nunes da Silva, a desejada vinda da "hora suprema e grande em que o nosso País se há-de libertar da secular mentira que o agrilhoa à noite do erro e da ignorância"(70); e, logo, no dia imediato, consumado o triunfo da revolução da Rotunda, faria protestar o seu amor "em nome da Verdade e da Justiça, em nome da Liberdade e da Razão, agora que sobre o nosso País amanheceu a grande madrugada", acabando a epístola entre febril ameaça de casamento e delirantes vivas à República ${ }^{(71)}$. Três meses decorridos, ao tom entusiástico do ditirambo libertário seguia-se a observação desencantada, não de um Saint-Just austero e ordeiro, mesmo sem as aras cívicas e os apostolados da Constituição, mas numa reprovação em severo tom de herculaniana dissensão. $\mathrm{O}$ acto de contrição, logo em Janeiro de 1911, aparece em epístola. Sardinha lamentava as tentativas de abate a João Franco perpetradas "pela matulagem de Lisboa", e temia a "facada mortal no prestígio da República! Como eu coro. Como eu me pejo do que está sucedendo. Eu que acreditei nestes homens, eu que me convenci que se faria alguma coisa! Não era um defeito de regime, é um

(70) Ana Isabel de Sousa Sardinha, "Quatro cartas inéditas de António Sardinha", A Cidade, n. ${ }^{\circ}$ 2, ob. cit., p. 171.

(71) Idem, ibidem, p. 172. 
defeito de raça! Falimos, nada nos salva! Daqui à tutela estrangeira é um passo! Como se enfuscaram os horizontes que há três meses eu vi abrirem-se para a pátria portuguesa! Pobre país o nosso, que entrou, creio-o bem, na crise final! Sem os anúncios da agonia! Arre, aventureiros! Arre, fraudulagem!"(72). Instalado na terra natal, experimenta, amargurado, o ostracismo: "Eu por aqui me arrasto", escreve Sardinha ao seu protector dos tempos da faculdade, em carta datada de Monforte, aos 29 de Março de 1912, "suspirando por me libertar dum meio onde me aguentam como thalassa retinto por haver mandado desentaipar a pedra dum brasão! O meu espírito, se no isolamento tem sonhado em intensificação individual e em observação, pelo esforço de se defender do meio anda com as faculdades criadoras muito em baixo"(73). É por esta altura que envia ao amigo, ainda emigrado, Almeida Braga a missiva em que confessa, entusiasmado novamente, a sua "conversão À Monarquia e ao Catolicismo"(74).

Desenganado das suas expectativas republicanas, com as "faculdades criadoras em baixo" - ele, que, em 1906, tentara dupla estreia literária sob o auspício, significativo pela antinomia, do patriarca da história da cultura, Teófilo Braga, a quem pedira prefácio para um projectado estudo sobre Cristóvão Falcão e de um poeta de renome académico, Eugénio de Castro, que lhe prometera prefácio para um livrinho de poesia ${ }^{(75)}$, que também não chegará a editar-, é, como amanuense, ainda, que começa a preparar o concurso para a Faculdade de Letras de Lisboa, com uma confusa tese sobre $O$ valor da raça, obra de estreia, algo frouxa, longínqua ainda do fulgor e de certo brilhantismo que manuseará em Aliança peninsular. Naquela instituição de ensino pontificava o prestígio de Teófilo, e do concurso fora afastado, por reprovação. Muito embora tivesse utilizado um estratagema da praxe, que consiste, como se sabe, na deificação da virtu intelectual do patriarca da Casa, tratava-se, de facto, de repisar as piores folhas do determinismo rácico (a antropogenia de

(72) Idem, ibidem, Carta de 15-I-1911, pp. 172-173.

(73) In "Correspondência...", ob. cit., p. 77.

${ }^{(74)}$ A Política, n. ${ }^{\circ} 10,10$ Jan. 1930, apud Manuel de Bettencourt e Galvão, Ao serviço d'el Rei, Lisboa, Edições Gama, 1949, p. 96.

${ }^{(75)}$ A. Pinto de Castro, no apêndice documental de "António Sardinha e o movimento literário do Integralismo Lusitano", $A$ Cidade, n. ${ }^{\circ} 2, o b$. cit., também publica estas duas cartas endereçadas ao editor França Amado, pp. 27-28. 
Haeckel) e do historicismo de rédea-curta teofiliano ${ }^{(76)}$, paridas, havia vinte anos, em Pátria portuguesa (1894), mesclando agora estranhas noções pseudoantropológicas e históricas, aduzidas com fracos argumentos de nova ciência e nula probidade, filiando portugueses actuais num atávico "dolicóide meão" que detectara em Mugen, tese que, improvável e improvada, acabaria por fazer cátedra no Porto e medrar na Sociedade Portuguesa de Antropologia, pela mão de Mendes Correia ${ }^{(77)}$. Ainda irá Sardinha reciclar a tese na conferência $O$ território e a raça (1915) e dela se servir para tema e filão inspirativo para uma veia poética, radicalmente anti-semita, quão rara nas letras portuguesas contemporâneas como constrangedora, apelativa ao fogo purificador do Santo Ofício e ao expurgo do sangue "pretóide" que correria em veias portuguesas; mas a ideologia racista (mais propriamente anti-semita ${ }^{(78)}$ ), no entanto, vai-se esbatendo e transmudando e não se encontra mais nos escritos finais, sobretudo na Aliança peninsular, onde raros vestígios, por exemplo, no "selo da Raça", nos aparecem como cambiantes metafóricas para um autêntico combate cultural e para a definição daquilo a que designa por um específico ethos lírico dos portugueses ${ }^{(79)}$.

Entretanto, na Universidade de Coimbra, onde esperou ser opositor a outro concurso, acabou por não ter ilusões de qualquer assento, não só dadas as poucas simpatias doutrinais com que contava do interior dos muros sapientes, como pela posição politicamente errática que tinha assumido, no curto espaço de dois anos, do acratismo ao republicanismo, e destes à monarcofilia, o que, obviamente, criara inevitável hostilidade entre republicanos, entre monárquicos conservadores e constitucionais, entre anarquistas (que tinham expressão nula nas cátedras). Não deixa de ser o desaire da projectada docência universitária um dado marcante para o perfil biográfico do intelectual, ao ponto deste escrever, aludindo ao facto, "isto", é um país "onde nem se reconhece o direito de mostrar o que a gente sabe" ${ }^{\prime \prime(80)}$ - explicação em tudo semelhante àquela que Teófilo

(76) Vide João Medina, "António Sardinha, anti-semita", A Cidade, n. ${ }^{\circ}$ 2, ob. cit., pp. 45-122, em especial 46-59.

(77) Idem, ibidem, pp. 50 e 77.

(78) Léon Poliakov, “O anti-semitismo é um racismo?", M. Wieviorka, Racismo e modernidade, ob. cit., pp. 84-86.

(79) Vide, v. g., "O Selo da Raça", in António Sardinha A Aliança peninsular, ob. cit., pp. 31-48.

(80) Idem, "Correspondência de António Sardinha...", ob. cit., p. 77. 
adiantara, noutros tempos também um preterido (um "absurdo") em Coimbra (um "charco"(81)) e que agora o preterira, a ele, em Lisboa. A estratégia universitária falhara. Restava o ensaio, o folheto, a agitação e propaganda dos novos ideais que se formam por 1912-1913, de modo pouco esclarecido, contudo, como atesta a primeira das mencionadas publicações. O púlpito e a táctica para a nova evangelização dos portugueses passariam a ser outros - a agitprop. Por seu lado, Hipólito Raposo que conseguiu lugar no aparelho republicano do estado, na Direç̧ãoGeral da Instrução Secundária, Superior e Especial ainda integrada no Ministério do Interior à data da sua admissão (1912), preparou oposição para esta mesma Faculdade de Letras de Coimbra, em Filologia Românica. A sua aspiração universitária também redundaria em desaire ${ }^{(82)}$. Quanto a Alberto de Monsaraz ou a Luís de Almeida Braga, sabe-se que nem sequer podiam frequentar as aulas como alunos ${ }^{(83)}$, pois se encontravam derriscados da Universidade de Coimbra, penalidade imposta pelo governo da República, por terem ingressado activamente nas incursões militares monárquicas lideradas por Paiva Couceiro em 1911-12.

Mas se no forum universitário não tinham assento, procuraram os integralistas não só intensa publicitação intelectual, mas também novas formas de agitação e propaganda políticas, nas revistas e nos jornais - e como o panorama existente não fosse receptivo ou conjunturalmente propício, criaram os seus próprios órgãos de imprensa, que são por si custeados (Monsaraz, Almeida Braga): primeiro, a mãe de água do reaccionarismo português de novecentos, a Nação Portuguesa, aparecida

\footnotetext{
${ }^{(81)}$ Amadeu Carvalho Homem, A ideia republicana em Portugal. O contributo de Teófilo Braga, Coimbra, Minerva, 1989, pp. 15 e 48.

(82) Em 1912, Hipólito Raposo fora opositor à cadeira de Filosofia da arte na Escola da Arte de Representar com a tese $A$ expressão no teatro, que não publicou (António Sardinha, De vita et moribus. Casos E almas, Lisboa, Ferin, 1931, pp. 210 -211). Em 1914, apresentou Sentido do humanismo (Coimbra, França Amado, 1914), dissertação para concurso à Faculdade, no qual defende, em tese geral, o carácter desnacionalizador do renascimento (p. ex., pp. 42-43 e 75-76).

${ }^{(83)}$ Mas tentam a todo custo concluir os seus cursos, facto visível na correspondência mantida com o Secretário da Universidade. Vejam-se as cartas de Almeida Braga, de 25 de Outubro de 1912 e de Monsaraz, de 5 de Outubro do mesmo ano, na qual este suspeita que gastara cinco anos da sua vida "a ouvir as preleç̧ões dos juristas da Lusa Creta" sem se poder formar. Cf. Idem, ibidem, pp. 105 e 85 (sublinhados nossos).
} 
em 1914, mas, também, o jornal diário lisboeta Monarquia, a partir de 1917, como induziram numa direcção integral o jornal académico monárquico coimbrão Pátria Nova ${ }^{(84)}$; depois, num último fôlego, em clara dissensão com a salazarquia, publica uma importante facção integral a revista mensal Integralismo Lusitano, entre 1932 e 1934, até ser involunta-

${ }^{(84)}$ O estudo do periódico académico Pátria Nova, editado em Coimbra entre finais de 1908 e meados de 1917, com diversas interrupções (pois a periodicidade do jornal depende do calendário escolar) e duas séries, vem trazer alguma luz sobre o processo de radicalização monárquica ou de conversão integralista que se foi verificando quer na linha editorial quer no horizonte reivindicativo e permite lançar a compreensão sobre as mudanças que se operam no movimento académico monárquico. A propriedade e direcção inicialmente de A. Duarte Silva, e secretariado por A. de Sousa Madeira Pinto e contando com redactores principais Agnelo Casimiro e Cordeiro Ramos, passa desde 1909 até Março de 1917, para a titularidade de propriedade do Centro Monárquico Académico, e a partir dessa data constitui-se, definitivamente, como "órgão de imprensa" da Junta Escolar Coimbrã do Integralismo Lusitano (cf. Pátria Nova, ano VI, II série, n. ${ }^{\circ} 12$, 26 Março de 1917) e financiada por esta, mas já mantinha uma linha integralista visível desde 1914-15. Na I série (1908-1911) o jornal destina-se a delimitar o campo monárquico, num publicismo constitucionalista e moderado, começando, no rescaldo do regicídio, pela aclamação de D. Manuel II e tentando estabelecer um frentismo monárquico, em torno do Centro Monárquico a cuja direcção pertenceram Alberto de Monsaraz, Simeão Pinto de Mesquita, Carneiro Pacheco, Luís W. Carriço e Domingos Fézas Vital ou Paulo Cancela de Abreu, e do qual foi colaborador Gustavo Cordeiro Ramos. É com a saída deste da redacção, em 1909, que se acentua a linha regeneradora liberal, facto visível, exemplarmente, no número dedicado quase em exclusivo às comemorações de Alexandre Herculano, no qual se saúda o intelectual que promoveu as fundamentais "polémicas contra o clericalismo do tempo", "o fanatismo inquisitorial" ou o homem que fulminou heroicamente o "fanatismo político" e o "absolutismo miguelino" (Pátria Nova, n. ${ }^{\circ} 48,30$ Abr. 1910, p. 1). A sua segunda série corresponde, de facto, a uma radicalização do discurso político até à definitiva absorção institucional pelo integralismo e pelo reforço de um imaginário elitista (veja-se, por exemplo, a coluna Smart set, a partir de 1914 até ao seu encerramento, e o interessantíssimo documento sobre a reminiscência de uma mentalidade sumptuária no n. ${ }^{\circ} 73$, II série de 6/2/1915), não tendo, contudo, a este título, colaboração doutrinariamente original, limitando-se a repetir, por vezes em excertos, os textos teóricos e a publicitar as posições políticas do Integralismo. A publicação é hoje muito rara, estando a colecção mais completa, segundo os dados que dispomos, depositada na hemeroteca da Biblioteca Municipal de Coimbra (as ${ }^{\text {cts }}$.correctas são: GHC-85 e GHC-98), tendo sido alguns dos seus exemplares, autógrafos, pertença de Luís de Almeida Braga. 
riamente encerrada, com termo de despejo e nota de despedida ${ }^{(85)}$, entre um sem número de publicações custeadas pela Junta Central, pelas Juntas escolares ou saídas em editoras comerciais de claro perfil conservador. A este título a produção crítica e ensaísta de Sardinha é impressionante. Apenas no espaço da década que medeia entre 1914 e 1924, ano em que gravemente adoece com a septicemia que lhe ditará a morte em Janeiro de 1925, desdobra-se em artigos, conferências, ensaios, continuando muitas vezes em prosa o verbo poético com que nascera para as letras, e desse esforço resultarão dezasseis volumes em prosa, a maior parte dos quais de compilação póstuma, e ainda sete volumes de poesia (alguns de época anterior). E tudo isto, contando com 27 meses de exílio, entre Badajoz, Toledo e o internamento de Madrid ${ }^{(86)}$, na sequência da sublevação de Monsanto (1919) o que permitiu à direita contra-revolucionária estruturar a sua própria cultura mitológica (e martirilógica) do exílio, sobre os sulcos que, nos séculos XVIII e XIX, estrangeirados e liberais românticos, por idênticos motivos de contrárias razões, trilharam.

O resto dos anos foram passados por António Sardinha, no seu retiro de Elvas, na Quinta do Bispo, a escrever, a ler, entretanto remetido a profundo desgosto com o falecimento do único filho, Lopo, que não chegou a festejar o primeiro ano de idade; tudo isto pontuado com deslocações frequentes a Lisboa, a Badajoz, raras a Coimbra, e entre algumas

(85) Vide, sobre a estrutura ideológica das duas principais revistas, Paulo Archer, Nação e nacionalismo, ob. cit., pp. 1-24; e "Da Nação Portuguesa ao Integralismo Lusitano. A insurreição dos intelectuais", art. e loc. cit.

${ }^{(86)}$ No Verão de 1919, o governo português procurou obter, junto do congénere espanhol, a ordem de internamento em Madrid para António Sardinha, argumentando com o perigo que para a República advinha do caso de se manter este exsenador monárquico em Badajoz, pois seria ele o elemento de ligação de todos os conspiradores anti-republicanos com exilados. Perante esta situação Sardinha reage, invocando a sua antiga recomendação do Conde de La Mortera (e a protecção por este assegurada durante o ministério presidido pelo pai), e reafirmando a sua condição de exilado político: "não oculto a minha situação de emigrado político", escreve ao Encarregado dos Negócios de Portugal em Madrid, "não oculto a inalterabilidade da minha conviç̧ão monárquica". O líder contra-revolucionário chegara a Badajoz, tendo sido registado na delegação de polícia a 25/II/ 1919 e efectivamente partiria, com ordem de internamento, para Madrid, a 30 de Agosto desse mesmo ano. Cf. António Sardinha, Glossário dos tempos, Lisboa, Edições Gama, 1937, pp. 255-259. 
experiências bizarras, como a de ter sido conferencista num programa de formação das universidades livres, facto justificável pelo elevado nível de relacionamento pessoal que, a partir da polémica, mantivera com alguns seareiros e com António Sérgio, em particular, com quem edita os dois números de Homens Livres (1923); ou como aqueloutra experiência de ter aceite a designação para a lista de deputados, a que efectivamente concorreu em Abril de 1918, recolhendo 2.807 votos pelo círculo de Elvas e entrando, efemeramente, no detestado Parlamento - dignidade registada em plena República, embora Nova e sidonista ${ }^{(87)}$.

De resto, as relações do sidonismo com o integralismo são muito extensas e os próprios elementos do pelicano reconheciam como seriam eles os veículos intelectuais a quem "caberia o destino de inspirar doutrina e colaborar com alguns diplomas de renovação política" do regime de um César matemático e germanófilo, muito embora considerassem o pretoriano sob suspeição, por estar, ao mesmo tempo, amarrado a "simpatias de antigo jacobino"(88). No seu discurso de ante-estreia parlamentar reivindica Sardinha a Monarquia, como princípio instituinte da ordem e da actuação dos monárquicos no Parlamento, que não poderiam agir, em circunstância alguma, como "partido" ou "facção": "A ordem não é um homem, a ordem não nasce espontânea na sociedade. A ordem é palpavelmente um princípio", considerando no entanto que "consagrando o poder pessoal dum homem", o país "consagrou a razão instintiva da sua formação monárquica". Por isso apelava aos monárquicos numa atitude construtiva em tudo o que dissesse respeito ao país e apelava à abstenção em tudo o que dissesse respeito ao funcionamento da República ${ }^{(89)}$. Mas colocava-se outra questão de fundo: o carácter inorgânico do cesarismo. Um quarto de século depois, em plena II Guerra

(87) Nas eleições de 28 de abril de 1918 os monárquicos, cuja facção mais representativa não era propriamente integralista, obtiveram 37 lugares na câmara dos deputados. Dos nove senadores que um decreto sidonista atribuíra previamente às "minorias" obtiveram os monárquicos oito lugares. Ao contrário do ocorrido na eleição presidencial de Maio, o único sufrágio directo em tempo de República, o nível de abstenção dos eleitores recenseados na eleição parlamentar passou largamente a cifra dos $60 \%$.

${ }^{(88)}$ Cf. Hipólito Raposo, Folhas do meu cadastro, ob. cit., pp. 35-36.

(89) Cf. António Sardinha, "No Parlamento", Na feira dos mitos, ob. cit., pp. 265-270. 
mundial, Luís de Almeida Braga, interpretando, com grande fidelidade, a posição de António Sardinha, afirmaria que "o Cesarismo é a negação da Monarquia", pois "consentir que a administração geral do estado estanque os particularismos locais [e corporativos], é aceitar as cadeias do Absolutismo" concluindo que "ditadura de César ou ditadura do Proletariado são afinal as duas faces, bem pouco diferentes, do mesmo estadismo tirânico e desumano" ${ }^{\prime(90)}$. Além do mais, havia que preservar a autonomia corporativa, muito embora nas chamadas Instruções $d a$ organização o grau de autonomia dos diversos "corpos" do Integralismo fosse diminuto ${ }^{(91)}$. E havia que sustentar, no plano orgânico, a sobrevivência própria de cada "pequena pátria regional"(92).

É muito conhecida uma afirmação de Umberto Eco, que tem feito escola, ao registar que Mussolini (e, por maioria de razão, o fascismo) "não tinha nenhuma filosofia: tinha só uma retórica"(93). Esta asserção sintetiza toda uma linha de investigação empírica, que se alicerça sobre textos teóricos ainda surgidos na década de trinta (Andrés Nin, Ortega y Gasset, C. Hayes, Daniel Guérin, em parte H. Rauschning, Benedetto Croce, Meinecke; após os anos cinquenta e sessenta, Hannah Arendt, George Mosse, Ernst Nolte, Eugen Weber, Barrington Moore Jr., depois, S. Payne, Z. Sternhell $\left.{ }^{(94)}\right)$, e que reforça o elemento do sincretismo ideológico,

${ }^{(90)}$ Luís de Almeida Braga, Posição de António Sardinha, Lisboa, Edições Gama, 1943, pp. 17-19, parêntesis nosso. Vide, também, António Sardinha, Em prol do comum, Lisboa, Livraria Ferin, 1934, pp. 170 e 171.

${ }^{(91)}$ Integralismo Lusitano, Instruções da organização. Aprovadas pela Junta Central, Lisboa, Empresa Nacional das Indústrias Gráficas (tip.), 1921, por ex: nas “Disposições Gerais" e nas "Disposições Especiais" vê-se bem o grau de reduzida autonomia que os corpos intermédios e menores gozavam, estando subordinados aos poderes muito vastos, sobretudo por omissão, da "Junta Central", pp. 13-15 e 6-7.

${ }^{(92)}$ José Pequito Rebelo, Duas economias, I parte, Definição filosófica, Coimbra, Junta Escolar de Coimbra do Integralismo Lusitano, 1931, p. 39.

(93) Umberto Eco, sobre o ur-fascismo, "O fascismo eterno", in Cinco escritos morais, Lisboa, Difel, 1998, p. 36.

${ }^{(94)} \mathrm{Na}$ década de noventa surgiram dois contributos notáveis para esclarecer do estado do problema; em geral: Stanley Paine, History of fascism (Historia del fascismo, Barcelona, Planeta, 1995, pp. 555-632); no contexto português, em confronto: António Costa Pinto, O salazarismo e o fascismo europeu. Problemas de interpretação em ciências sociais, (Lisboa, Estampa, 1992, p. ex., pp. 17-40). 
ocasional, assistémico, irracional (Luckács), culturalmente fragmentário (e não com a compacticidade revolucionária que Mosse afirmara), produto da repressão sexual da sociedade burguesa (Wilhelm Reich, Erich Fromm) que conduziria a uma "personalidade autoritária" (porque as atitudes etnocêntricas, antisemitas, antidemocráticas já estariam instaladas no interior das próprias práticas e discursos sociais, o autoritarismo extremo apenas acentuaria o momento da autodestruição da razão para instauração de uma "razão perversa" - Adorno, Horkheimer, Herbert Marcuse), ou, então, conduziria ao amorfismo das massas, mudança qualitativa significante, pois que se encontrariam as massas "preparadas" para beber, hipnotizadas, seduzidas, o discurso irracional, a voz (Derrida) e para a dimensão da "estética" da força e do espectáculo da violência que o fascismo pressupunha (Ortega e Arendt).

Embora possamos pensar que a afirmação de Umberto Eco é uma tirada digna de um literato e professor medievalista, pelo exposto - e exceptuando os que defendem o carácter estruturado e revolucionário do fascismo, com Mosse à cabeça, sobretudo se pensarmos nas teses de Nolte e do entendimento do fenómeno metapolítico e das "metas transcendentais" do populismo, que o fascismo representa -, o sincretismo tem sido considerado factor determinante para a análise da formação da ideologia fascista e nazi. Acaba por ser esta uma afirmação esclarecedora quando cotejamos com um certo grau de compacticidade estrutural que o discurso integralista possui e, até, com um certo nível de sistematicidade, sobretudo adquirido após a desilusão da actuação política imediata e passada a necessidade de apelo à aç̧ão directa, o que só ocorre na conjuntura post-1919, momento a partir do qual Sardinha escolhe a via do exílio espanhol - que cumprirá intermitentemente, de resto -, o que lhe permite uma perspectiva mais distanciada da sociedade portuguesa e o impele, por fim, para a consideração de uma dualidade hispânica, onde desaparece qualquer resquício de maurrasianismo político, aspecto que já sustentámos em tese geral ${ }^{(95)}$ e que, verdadeiramente, se inicia com uma conferência homónima proferida em Madrid, em Abril de 1921.

(95) Paulo Archer, Nação e nacionalismo, ob. cit., pp. 123-125, e "De Sardinha a Salazar. O nacionalismo entre a euforia mítica e a 'formidável' paranóia", Revista de História das Ideias, vol. 17, ob. cit., pp. 88-89. 
De facto, é a partir dessa época que o pensamento estratégico integralista se altera profundamente - e não terá sido apenas responsável por esta mudança a dupla derrota político-civil e militar da chamada Monarquia do Norte e da sublevação de Monsanto, mas também o contacto estremenho e madrileno, o triunfo, bem ilusório, das democracias liberais na I Guerra mundial, que impulsionaram Sardinha para a construção da tese da aliança peninsular (que já tinha sido esboçada em 1917 , mas a sua directriz teórica sofreu uma inflexão tomista $\left.{ }^{(96)}\right)$, supra-nacionalismo ibérico, pan-hispanismo messiânico também definido como internacionalismo hispânico ${ }^{(97)}$, dualidade e alteridade de uma mesma realidade peninsular, católica, proselitista e ecuménica, arma de arremesso político a cultural erigido contra o iberismo republicano oitocentista, e o federalismo "desnacionalizador", produto de uma "ideologia arcaica", como escreve António Sardinha, "saída dos conventículos maçónicos da Revolução"(98). Esta visão superava o estrito sentido nacionalista, como consciência política de si de uma comunidade que se reflecte sobre si mesma, para se envolver numa percepção ou espécie consciência cultural (de longe, o aspecto mais apelativo da escrita de Sardinha) traduzido por um, assim chamado, génio peninsular, ou hispânico, precisará Sardinha, no sentido próprio em que Oliveira Martins considerava, a propósito de Os Lusíadas, e até de Camões, constituírem estes o "testamento de Espanha", mas de uma Espanha antevista agora

(96) Carlos Ferrão, numa obra polémica, O integralismo e a república. Autópsia de um mito, vol. 2, Lisboa, Editorial Inquérito, 1964, depois de analisar o posicionamento errático de Sardinha perante a I Guerra Mundial, adverte para o facto de já em 1917 este ter enunciado a tese da aliança peninsular nas páginas do periódico A Monarquia (pp. 232-233). No entanto, a estruturação teórica só nos aparece em 1922 e completamente articulada na edição do volume homónimo, em 1924. Essa informação acaba por ser irrelevante pois se não há dúvida que o esboço estratégico já tinha sido fixado, não estava estabelecida a determinante valência ideológica. O que Ferrão escreve, seguindo as pisadas de Alfredo Pimenta num opúsculo violento contra Sardinha, é que o hispanismo era uma tese antipatriótica e "perigosíssima". Na década de 70 Franco Nogueira repetiria a mesma tese.

(97) António Sardinha, À lareira de Castela, Lisboa, Edições Gama, 1943 (1944), p 178.

(98) Idem, A aliança peninsular. Antecedentes $\mathcal{E}$ possibilidades, 3. a ed., Lisboa, Biblioteca do Pensamento Político, 1972, pp. 51-52. 
como a conceptualização de uma "comunidade espiritual", "nunca de uma exígua e exclusiva designação nacionalista"(99).

Esse nível de sistematicidade teórica - que tem desagradado a alguns, que preferem negar a evidência a tentar compreendê-la e integrá-la numa leitura abrangente da história e da cultura portuguesas da primeira metade do século XX - revela-se na capacidade de articulação do programa de 1914 (organicidade, autonomia corporativa e autárquica, municipalismo, afirmação do poder pessoal do rei e de uma constituição consuetudinária pré-constitucionalista) com o providencialismo histórico, ou uma espécie de misticismo social que o nacionalismo orgânico vai ganhando cada vez mais nos textos de 1922 a 1924. É a componente do pensamento gnóstico que emerge do terreno do combate político, pois a hispanidade e o catolicismo são os dois grandes dispositivos teóricos capacitados para o combate tradicionalista, um combate pelas consciências, um combate contra os chamados materialismo anglo-saxónico e o capitalismo protestante - dir-se-ia que a luta contra a laicização da sociedade portuguesa, mediante esta nova visão "supranacional", acabava por, conjugadamente, colocar em segundo plano a questão do regime, que, no entanto, sempre se colocará como reivindicação necessária, mas não suficiente. Diga-se, de modo objectivo: o ideal de unidade (o que em linguagem nacionalista, quer dizer, coesão, metaforicamente representada pela ideia de familia descendente do pater comum $\left.{ }^{(100)}\right)$ que o nacionalismo integral transporta acaba por ser mais abrangente, no interior de uma sociedade ruralizada e analfabetizada - isto é, sem capitalismo, nem livro (B. Anderson) ${ }^{(101)}$ - e na qual o mundo das palavras é, em grande parte, oral $^{(102)}$, do que o nacionalismo fracturante (quebra da tradição dinástica, generalização da escrita, discurso político dessacralizador) do republicanismo hegemónico de 1910. Com efeito, pretendendo convocar (no fundo, reinventar) a cultura tradicional, mobilizando a heroicidade mítica, as formas tradicionais de religião (congregação), despertando na paixão

\footnotetext{
(99) Idem, À lareira de Castela, ob. cit., p. 154.

${ }^{(100)}$ Cf. Anthony D. Smith, La identidad nacional, Madrid, Trama Editorial, 1997, p. 69.

(101) Vide em José Manuel Sobral, "A formação das nações e do nacionalismo", Análise Social, vol. XXXVII, (165), 2003, pp. 1100-1101, um resumo da tese de Anderson.

${ }^{(102)}$ E. Hobsbawm, A questão do nacionalismo. Nações e nacionalismo desde 1780 , Lisboa, Terramar, 1998, p. 109.
} 
e graça da terra - o tema da terra pátria - uma emotividade própria do "encanto rural" (103), não com a wagneriana violência da antimodernidade ecológico-pastoril nazi (que se ouvia, nos campos de concentração), mas com a sedução bucólica das canções de giesta ${ }^{(104)}$, o integralismo atingia um território sociológico mais vasto: a imensa legião de camponeses e lavradores, de vilãos pobres e iletrados. Por isso, encontrando-se na encruzilhada entre um urbano e futurista mundo novo e o velho mundo da sociedade agrária, e dos ritos de congregação, o integralismo percebeu como era esta imagem conservadora, contra-revolucionária (portanto, não-revolucionária), mas milenarista, aquela que lhe convinha optar como discurso de convicção.

O hispanismo, projecto ucrónico, desencadearia novos focos de tensão ideológica nas hostes contra-revolucionárias. Após a morte de Sardinha e após o triunfo do pronunciamento militar de Maio de 1926, e com a estabilização do Estado Novo, constituirá o maior motivo de dissensão ou de querelas abertas entre os próprios integralistas, a par da questão dinástica: uns acolhem-se à sombra tutelar de Salazar (Manuel Múrias ${ }^{(105)}$, João Ameal, Teotónio Pereira, Marcello Caetano), outros mantêm a independência intelectual (Hipólito Raposo, Pequito Rebelo, este até ao deflagrar das guerras coloniais), outros, como Alberto de Monsaraz, radicalizam posições, ingressando nas hostes nacional-sindicalistas de Rolão Preto, também ele nascido politicamente da própria matriz integralista, embora releia, e refute, na prática, na perspectiva já não da politique d'abord mas do assalto ao poder, o sentido místico e o gnosticismo em que Sardinha cada vez mais mergulhara. Com efeito, os nacional-sindicalistas cedo perderam o forte conteúdo gnóstico e proselitista que o integralismo reinvidicara: o espírito de cruzada dos camisas azuis era

${ }^{(103)}$ Tom Nairn, "La maldición del ruralismo: los limites de la teoría de la modernización", Jonh A. Hall (ed.), Estado y nación, ob. cit., p. 181.

(104) Veja-se, por exemplo, Luís de Almeida Braga, Alberto de Monsaraz. No jardim das rimas, separata da revista Gil Vicente, Guimarães, vol. III, $2^{a}$ série, 1952, pp. 6-7, num ataque ao nada da poesia moderna. A estabilidade da língua - e das suas múltiplas expressões - é um factor de "claridade essencial", para a estabilização do ideal de unidade nacional (Elie Kadourie, Nacionalismo, Madrid, Centro de Estudios Constitucionales, 1988, p. 53).

(105) Cristina Pacheco, "Os Integralistas no Secretariado de Propaganda Nacional", Clio, Revista do Centro de História da Universidade de Lisboa, Lisboa, Colibri, 1997, pp. 137-152. 
outro - mais próximo de Homem Cristo Filho ou de Henrique Trindade Coelho-, e reforçava a urgência de uma "revolução nacional dos trabalhadores $^{\prime \prime(106)}$ nem que fosse preciso, para triunfar a Ordem Nova, crucificar a Igreja. Ora, isto seria impensável para os integralistas que acolheram Sardinha como líder tradicionalista incontestado entre 1914 e 1925.

Para reforçar a tese segundo a qual o integralismo quer ganhar a batalha da elite intelectual bastaria ler de Sardinha a sua Teoria da nobreza, escrito de Agosto de 1916. Aí se defende o carácter de uma nova aristocracia que deveria emergir nos escombros da sociedade faústica. Num tom martiniano, o autor de $A$ epopeia da planície, reverbera a aristocracia decadente de armorial no dedo e de livro de actas autojustificativo: "Como em Portugal não há um destino, como em Portugal não há uma ideia directriz, também em Portugal não há uma nobreza", confessava ${ }^{(107)}$. E ia acrescentando, "com a Profissão e com a Nobreza [entenda-se: a futura aristocracia intelectual] é que o rei de Portugal - e não o minúsculo rei dum partido -, empreenderá a restauração da Pátria pela Monarquia". Só sob a liderança do monarca (nem se perceberá, após 1922-23 de qual

(106) Rolão Preto, Orgânica do movimento nacional-sindicalista, (Lisboa, 1933), apud António Costa Pinto, Os camisas azuis. Ideologia, Elites e movimentos Fascistas em Portugal. 1914-1935, Lisboa, Estampa, 1994, p. 157. É muito discutível a sustentação de Costa Pinto, segundo a qual o Integralismo constitua a autêntica matriz ideológica do Nacional-sindicalismo. Em primeiro lugar, ela é redutora, pois não toma em consideração devida a alteração estratégica e ideológica que ocorre no Integralismo, por via de Sardinha, post-1919, sobretudo na obra produzida entre 1922 e 1925 (cf. pp. 25-31). Em segundo lugar, afirmando embora que o nacional-sindicalismo foi "um derivado fascista do Integralismo" (p. 224), o que se nos afigura correcto, não explora o A. a posterior tensão existente entre os Integralistas de charneira (Hipólito Raposo, Pequito Rebelo) e os nacionalsindicalistas: a própria recepção díspar da ascensão fascista em Itália, e do debate sobre a legitimidade da violência política que esta pressupõe, por parte do integralismo doutrinariamente instituinte, nos anos 20, é a prova cabal do que afirmamos (cf. P. Archer de Carvalho, Nação e nacionalismo, ob. cit., pp. 112-122) pois não é unívoca a análise de um Rolão Preto, de um Manuel Múrias ou de um Marcelo Caetano. Em terceiro lugar, e talvez decisivamente, não toma em linha de conta - ou não utiliza como facto já conhecido e interpretado - que o hispanismo é a autónoma resposta política do Integralismo à disputa pela hegemonização do conceito de latinidade, que opõe, no campo reaccionário, Maurras e a action française a Mussolini e ao fascio italiano (cf. Idem, ibidem, pp. 123-132).

${ }^{(107)}$ António Sardinha, Ao princípio era o Verbo, ob. cit., p. 234 (parêntesis nosso). 
monarca se fala, após a ruptura que os integralistas provocam com D. Manuel II e com os seus seguidores constitucionais) esse desiderato seria alcançado; em todo o caso, de um monarca que seria o corporativo "chefe natural da Inteligência e do Trabalho", que permitiria a "instauração da ordem social cristã" com base numa legitimidade que assentaria no "sufrágio dos séculos"(108). Quanto ao mundo "Profissional", como se escreve, também ele deveria encontrar, através dos seus mecanismos de representatividade, lugar para o intelectual operário, uma espécie de elemento de elite, zeloso e sábio dos segredos profissionais: quando o Ateneu de Lisboa defendeu e promulgou um programa de cultura popular, aparece Sardinha a defender o surgimento de uma "intelectualidade profissional" no meio operário. Mas náda de confundir as desiguais calotes da esfera: se os génios se reservam ao cultivo das esferas mais elevadas, assim aos operários se deixa o simples estudo da actividade laboral ${ }^{(109)}$. Ao ensaiador de filosofias, ao leitor e comentador compulsivo, ao polemista (menos efémero do que se supôs), ao escritor (mais brilhante do que o lusco-fusco de certa historiografia de encomenda catalogou), muito embora lhe fosse dado encontrar o seu heimat, que se situava, cada vez mais, numa miragem de mística gruta no interior do deserto, um deserto que se lhe assemelhava de bárbaros e de descrentes, ao político (provavelmente ingénuo e, por isso, inábil), não lhe faltava somente a passagem ao acto: faltava-lhe, sobretudo, encontrar a mítica reactualização de um certo D. António, Prior do Crato, ou de um Macbeth, que fosse: mas de um qualquer rei que partisse do nada à procura dum reino. O problema destes monárquicos, em era republicana, agravar-se-ia à medida que não mais encontrassem o monarca.

Contra a decadência, entre o povo e o rei, os intelectuais do campo integralista, que ainda se pensavam e auto-representavam como a emanação, duêndica e romântica, da vox populi do passado, propunham a instauração mítica de Portugal num contexto, interno e externo, em que nem sombra era já do sol extinto. Relembre-se o que há pouco se registou sobre o ethos lírico dos portugueses: o que Sardinha escrevia era mais típico de uma verdadeira mentalidade sincrónica e de uma conjuntura intelectual (1890-1930), do que original página por si pensada, reflexo

${ }^{(108)}$ Idem, Glossário dos tempos, ob. cit., p. 312.

${ }^{(109)}$ Cf. idem, Ao ritmo da ampulheta, ob. cit., 1925 (o Autor revia as provas, quando faleceu), pp. 237-238. 
diurno do medo da "morte da nação" na qual, como em nenhum tempo, depois do fim das embarcações do Auto da Índia, toda a pequena multidão da inteligentsia (a que vivia entre os gongos da Cabra e a que escrevia no Martinho da Arcada) se questionava obsessivamente, em prosa, em verso, em luzes, em sons, sobre a identidade nacional: Antero, Oliveira Martins e Sampaio Bruno, Alberto Sampaio e Sobral Cid, Teófilo, Amorim Viana, Nobre e Junqueiro; Eça e João de Barros, Gomes Leal, Bruno, Pascoaes, Pessoa, Almada, Sá-Carneiro, Jaime Cortesão, Leonardo, Sérgio, Proença, Raul Brandão, Aquilino Ribeiro, Afonso Duarte, Laranjeira, Lopes Vieira, Columbano, Rafael, Mâlhoa, Lino, Eduardo Viana (também Amadeo e a sua fixação pelas cores térreas), Freitas Branco, Keil, Viana da Mota, etc.

Só que a República prometera para o dia imediato, antes de se implantar no momento do triunfo (leiam-se os preâmbulos dos primeiros decretos), num superlativo nacionalismo, retórico, a radical regeneração de Portugal. Bastava ouvir o Hino marcial de Lopes de Mendonça e a batida dos címbalos dos canhões, como se fosse um eco de um tempo imortal que esbarrava nas paredes do presente, para se compreender como esse mundo novo prometido (no que fosse mais parecido com o esplendor mítico do passado) estava aí a chegar, ao Calhariz. Afinal, Teófilo, o "mestre da contra-revolução", posteriormente renegado, que politicamente prometera em 1880, algo pouco menos que o próprio Camões em pessoa (cujo programa serviu de fonte à triunfal, e falhada, estreia republicana, conta José Gomes Ferreira, da $1^{a}$ Sinfonia camoniana de Rui Coelho) - não sabemos se chegou a aperceber-se do outro (o Pessoa em pessoa, do super-Camões, que considerava, de resto, aquela República um acto de incompetência intelectual $\left.{ }^{(110)}\right)-$, nada tinha para, politicamente, oferecer ao discurso autolegitimatório que o republicanismo fundara: nem império, nem presente, apenas uma mitologia e uma retórica do passado, que eram, estranhamente, os instrumentos para edificação do Progresso e para a contagem de espingardas na bateria iconográfica da nova religião cívica (da qual o pensamento democrático era um anjo ausente). Em tudo isso, mas só nisso, os outros nacionalistas, os que se tinham oposto à República, puderam compreender o carácter retórico do poder republicano e a partir daí desenvolver as suas estratégias de convicção, que certamente não eram de menor retórica nacionalista, mas que os persuadia estarem dentro duma certa razão histórica: primeiro,

${ }^{(110)}$ Fernando Pessoa, Da República (1910-1935), Lisboa, Ática, 1979, p. 140. 
porque o ditirambo que continha o verso apaixonado da grande madrugada, nunca mais amanhecia; depois, porque a madrugada já não era aquela.

Entenda-se: o discurso anti-intelectualista que inicialmente os intelectuais do campo integral propunham (Les méfaits des intellectuels de Édouard Berth, aparecido em 1914, foi uma espécie de Bíblia apócrifa dos integralistas até aos anos 20) não visava, tão somente, o campo democrático, republicano ou socialista dos intelectuais portugueses, pois visava a "desnacionalização" capitalista, o liberalismo, o constitucionalismo monárquico, a manifestação da descrença religiosa. Se dúvidas houvesse sobre a ruptura que a modernidade instaura no mundo aristocrático de Antigo regime (no qual se incluía a cleresy de Gellner ${ }^{(111)}$ ), este é o momento, o da análise do movimento reaccionário, para percebermos que, apesar da persistência de algumas continuidades longas significativas (língua, poder municipal, ruralismo e imaginário honorífico), essa cisão moderna criou feridas abruptas: antes de mais, pelo facto da cultura letrada passar a ser um requisito da sobrevivência generalizada e não uma especialização cujo segredo impunha certas regras internas (constrições, exclusões, celibato, hereditariedade, etc. $\left.{ }^{(112)}\right)$, pois bem: o problema da ignorância dessa cultura urbana, das letras e dos números, numa sociedade periférica e cheia de "ruínas rurais", não é um problema colocado, ou pensado, pelos integralistas, que parecem, nesse domínio, defender privilégios de casta, embora com sensibilidades diferentes sobre esta questão ${ }^{(113)}$. Ora, o que parece ter acontecido no caso português foi que a emergência do nacionalismo messiânico e regenerador, nas suas

${ }^{(111)}$ Ernest Gellner, Nações e nacionalismo, Lisboa, Gradiva, 1993, pp. 21 e 34-35.

(112) Idem, ibidem.

${ }^{(113)}$ Em 1916, propunha Martinho Nobre de Melo, um elemento muito próximo do integralismo de charneira, uma curiosa movida tradicionalista onde, "artistas e intelectuais" fizessem propaganda gratuita da arte e do bom gosto, em como que Universidades livres [no momento em que estas começam a surgir como estratégia impulsionada por intelectuais democráticos e anarquistas]" fazendo "apoteoses magníficas de quanto se adivinhe atinente a desenvolver o sentido das formas belas e a ternura pelas coisas suaves, como sejam as danças clássicas, costumes regionais, a arte do lar, enfim todo um programa". Numa segunda fase, protagonizava uma "associação de classe de literatos e artistas", "cuja influição benéfica não tardaria, libertando-os das garras dos editores-livreiros" - cf. Martinho Nobre de Melo, Para onde vamos? Um aspecto do problema nacional, Lisboa, J. Rodrigues \& C. ${ }^{\text {, }}$ 1916, pp. 38-39. 
diversas expressões ideológicas (constitucionalismo, republicanismo, autarcia salazarista) e nas suas diferentes práticas sociais e políticas, não foi acompanhado de mudanças bruscas no tecido social: a emergência do nacionalismo não se vinculou à irrupção de uma industrialização abrupta, violenta, - que em verdade, nunca chegou a acontecer em Portugal - óbice maior de aplicação que o "modelo ideal" de Gellner comportava $^{(114)}$. Para se compreender a emergência autoritária de um nacionalismo agressivo post-1918, dada, em Portugal, a comprovada incapacidade do estado moderno instituir a democracia (é a conjugação de M. Mann $\left.{ }^{(115)}\right)$ e de promover as mudanças que uma sociedade arcaica e periférica exigia, não se verificando nem o salto da produção industrial nem a constatação de uma sociedade de elevadores avariados (em termos da mobilidade social), diga-se que a liquidação parcial do tipo de legitimidade moderna (representação, autonomia do político) foi executada em nome de uma legitimidade de tipo tradicional (status, heteronomia).

Portanto, as massas, na inicial definição integralista, enquadradas organicamente pela elite intelectual das elites, e pelo conceito enquadrador de monarquia, encontrariam (no Programa de 1914) um "equilibrio orgânico" entre a família, os sindicatos (corporações) e os municípios, o que implicava a rejeição do sindicalismo revolucionário como "método positivo" de solução da questão social e implicava, de igual modo, a sua integração pelos princípios hierarquizadores e enquadradores da Igreja ${ }^{(116)}$. Embora ainda se citassem nas bibliografias as obras de Sorel, e nas recomendações de leitura das diversas publicações, só as de Valois (L'homme qui vient ou La monarchie et la classe ouvrière), faziam sentidopois o "gremialismo" destinava-se agora a liquidar o sindicalismo revolucionário $^{(117)}$. Entretanto, perdidas as expectativas imediatas da tomada do poder político pelos intelectuais, encontrar-se-iam sucedâneos e definições menores para o conceito de massas no ocaso do integralismo: "rebanho acéfalo dos explorados" a quem a "ordem burguesa" concedera

${ }^{(114)}$ Nicos Mouzelis, "La teoría del nacionalismo de Ernest Gellner: algunas cuestiones de definición y de método", in Jonh A. Hall, Estado y nación, ob. cit, pp. 212-221. Elia Kedourie, Nacionalismo, ob. cit., pp. 117-118.

(115) Anthony D. Smith, Nacionalismo y modernidad, Madrid, Istmo, 2000, pp. 158-161.

${ }^{(116)}$ Cf. Integralismo Lusitano (Monsaraz, ed.), Cartilha do operário, 3. a ed., Lisboa, Soares \& Guedes, 1921, pp. 53-57.

(117) António Sardinha, Ao princípio era o Verbo, ob. cit., pp. 303-304. 
"o protesto ruidoso e até sanguinário da greve"(118), ou, então, classe contaminada, desde Heine, Marx e Lenine, pelo "milenário ódio judaico" que "satanicamente" conseguiu comandar "legiões imensas de cristãos", numa outra variante do discurso, mais próxima do registo interior do nacional-sindicalismo, embora ainda mediada pela ideia da Providência que, no Calvário, reencontrara a humanidade ${ }^{(119)}$. Mas não eram, propriamente, as massas para os integralistas, aquele poppolo fascista, de que a rivoluzione falava quando prometera, pela voz de Mussolini, "andare verso il poppolo" e marchar contra a "plutocracia oligárquica" do capitalismo internacional ${ }^{(120)}$, na sua dupla aspiração à criação de uma nova "civilização" e de uma "nuova civiltà"(121), as quais, nas palavras de Ricci assentariam na necessidade de combater "in noi stessi e nel costume civile ogni avanzo del materialismo antistorico e antiquato, vero oppio del poppolo e religioni per signore"(122). Aqui, nesta nova civilidade, se anota como religião de senhores e ópio do povo eram agora sinónimos de materialismo "anti-histórico" - mas também o era, nos contrários termos, à luz da revolução social do fascismo, a religião romana e católica. Não eram estas as massas que os intelectuais integralistas procuravam convencer, porque não eram católicos, como dissera Maritain, os pais do mundo burguês ${ }^{(123)}$. Talvez a melhor definição integralista de massas se pudesse encontrar num nacionalista conservador, para quem "característica essencial das massas, como elemento social, é", escreve Carlos Selvagem, "a incapacidade de criarem, de construir seja o que for em seu próprio benefício e de, sentindo-se vulgares, imporem orgulhosa e autoritariamente a sua própria vulgaridade" (124). Numa cambiante ainda mais rural, e corporativa, seria esta a versão do salazarismo.

${ }^{(118)}$ Manuel de Bettencourt e Galvão, "A ordem burguesa", in Ao serviço d'el Rei, ob. cit., p. 13.

(119) Eugénio de Belonôr (?), A revolução social, Águeda, Reacção, (1933), p. 27.

(120) Vincere (ext. de discursos comentados de Hitler e Mussolini), Roma, Tip. "Europa" s. d. (1941?), pp. 27-36.

(121) Renzo De Felice, Mussolini. Il duce. II. Lo stato totalitario, 1936-1940, Torino, G. Einaudi., 1981, pp. 255-330.

(122) Apud De Felice, ibidem, pp. 304-305.

${ }^{(123)}$ Apud João Ameal, No limiar da idade-nova (ensaios contemporâneos), Coimbra, Imprensa da Universidade, 1934, p. X.

(124) Carlos Selvagem, O problema das elites no mundo moderno, Lisboa, Pro-Domo, 1944, p. 25. 
Ora, ao legitimarem o nacionalismo tradicionalista e autoritário, formulando-o a partir de uma noção mítica de identidade (heroísmo, providencialismo, messianismo), sobrevalorizando a função integradora do jus soli em detrimento do apelo à limpeza étnica do jus sanguinis (Hastings $\left.{ }^{(125)}\right)$, os doutrinários do campo integral estavam a legitimar a sua própria identidade como intelectuais, perante o generalizado questionamento das "tradições cósmicas" que eles próprios defendiam ${ }^{(126)}$, definindo o campo, porém, com uma concepção hierárquica e corporativa da cultura política, que, na fronteira, recusava às massas qualquer aspiração de autonomia e qualquer hipótese de sindicalismo. O que há de especificamente moderno nesta questão é que o sacerdos nacionalista das "campanhas de resgate"(127) não é o clérigo, nem faz parte da cleresy orgânica da Igreja. Mas os sinais que produz - a linguagem (apesar de alguma violência retórica) - coadunam-se mais com a legitimidade tradicional (conceito de herança nacional, Hume, Burke ${ }^{(128)}$ ) do que com a emergência de uma legitimidade nova e "revolucionária", mesmo que ideologicamente contra-revolucionária. Ora, por aqui se confirma, como a questão da legitimação é, sempre, uma velha questão de intelectuais ${ }^{(129)}$.

\section{O nosso reino não é deste mundo (sobre o "outro Portugal da outra-Vida")}

Sendo antiutopista, o integralismo acaba, afinal, por segregar a sua própria utopia, cujos segmentos influenciaram no post-I Guerra Mundial toda a direita radical portuguesa, antidemocrática e autocrática, e que se pode estabelecer como sendo uma Ucronia, não já no sentido que Renouvier lhe conferira mas neste outro: dispositivo derradeiro da ilusão, típica dos intelectuais que se auto-representam como vanguarda, neste caso a vanguarda nacional, que legitima a ideia de ser o verdadeiro poder

(125) Adrian Hastings, La construcción de las nacionalidades, Madrid, Cambridge University Press, 2000, pp. 50-51.

(126) Cf. Anthony D. Smith, La identidad nacional, ob. cit., pp. 82-89.

(127) António Sardinha, De vita et moribus, ob. cit., p. 211.

${ }^{(128)}$ Dominique Schnapper, La comunidad de los ciudadanos. Acerca de la idea moderna de nación, Madrid, Alianza (col. Ensayo), 2001, pp. 60-61.

${ }^{(129)}$ Contra: Ernest Gellner, Dos nacionalismos, Lisboa, Teorema, 1998, p. 84. 
intelectual o poder de governar, pressionando, convocando os saberes, os que governam o mundo (seja a nação, o mundo ecuménico, ou a instituição clerical): mais do que o filósofo do rei, muito embora em alguns trechos possamos pensar que é disso que se trata, os intelectuais integralistas, refiro-me a António Sardinha, pretendem assumir verdadeiramente o papel do rei-filósofo da comunidade nacional ou de uma mítica comunidade ecuménica, e isso criou um território teórico de possibilidade, que visava também a consumação daquela fuga simbólica para o imaginário imperial de que fala Eduardo Lourenço ${ }^{(130)}$.

E essa ilusão jogava-se, bem entendido, num tempo sem tempo, ou num tempo congelado, isto é, num tempo sem temporalidade. É este o verdadeiro mito integralista que o salazarismo ressuscita: ele cria a ilusão de um tempo em suspensão, de uma história presentificada, ou emparedada entre parêntesis magestáticos do passado, e cria a ilusão de ser o real imediato uma passagem, um ritual constrito, entre um passado quase eterno (ou miticamente eternizado) e a eternidade futura, onde, no limite, todo o pensamento é desnecessário e a liberdade inútil ${ }^{(131)}$ : tudo faria parte, nesse registo optimista, de uma reconciliação cósmica com um universo divinizado, de uma nova organização económica e social cristã - era este o registo da indispensável "revolução social" que Sardinha preconiza ${ }^{(132)}$. Esta era a via para o triunfo da sociedade ucrónica: porque, em última análise, toda a história seria remorso e esquecimento e humano pecado, como de Santo Agostinho a S. Tomás de Aquino, pregavam os doutores da Igreja.

Por isso o Integralismo Lusitano, ao definir-se como um projecto dúplice contra a modernidade e as suas manifestações, desde logo contra a própria dimensão estética do modernismo, e contra a ideia de contemporaneidade ${ }^{(133)}$, em geral, e ao contrário do fascismo e do nazismo - que contêm na sua estrutura amalgamada fragmentos diversos, mas visíveis,

(130) Eduardo Lourenço, Portugal como destino seguido de mitologia da saudade, Lisboa, Gradiva, 1999, pp. 56-57.

(131) Vide P. Archer, "De Sardinha a Salazar. O nacionalismo entre a euforia mítica e a formidável paranóia", Revista de História das Ideias, vol. 17, ob. cit., pp. 122-123.

(132) Cf. António Sardinha, "Ocidentalismo e Cristianismo", Nação Portuguesa, série IV, (1926-1928), f. IV, p. 253.

${ }^{(133)}$ P. Archer, "A insurreição dos intelectuais", art. e loc. cit., pp. 143-147. 
daquilo a que Jeffrey Herf chama modernismo reaccionário(134), embora de espessura e de articulação variáveis -, acabou por se constituir numa dianóia paralisante das mobilidades sociais e da ideia de emergência da história, pois se baseava nuclearmente nas filosofias do eterno retorno ${ }^{(135)}$ e da revelação providencial.

Qual a ucronia, proposta por Sardinha? Começara por se gerar a ideia numa contradição profunda, como em Herculano, como no romantismo liberal e nacionalista, entre a constatação da decadência do presente e a glória mítica de um passado improvável ou indocumentado. Apelava-se, por um lado, ao sentido mítico da ancestral grandeza nacional e imperial (apesar do imaginário colonial não ser particularmente intenso, nem grado, em Sardinha, nem ocupar espaço autónomo nos seus ensaios, senão como plataforma do espaço atlântico, do mare nostrum e das suas "margens", a Península Ibérica e a América Latina), dispositivo de recriação da glória perdida da potência mercantil, para se denegar a "superstição democrática"(136) e o crepúsculo da liberdade individual, diga-se, das liberdades concretas dos concretos indivíduos. Por outro lado, ressuscitava Sardinha uma mitologia perdida (tão longínqua que faria recuar o dolicóide meão de Mugen até à lendária Atlântida, trazida dos antigos Gregos pelos Judeus, que ele renegava, uns e outros, pagãos

(134) É o próprio título do estudo de Jeffrey Herf, Reactionary modernism (New York, Cambridge University Press, 1984), que sustenta, em tese geral, a preexistência, à data da tomada do poder por parte dos nazis, de uma importante corrente do pensamento conservador alemão (nos quais inclui Oswald Spengler, Ernst Jünger, Carl Schmitt, Hans Freyer ou Werner Sombart) e que produz a reconciliação entre as ideias antimodernistas, românticas e irracionais, características já do nacionalismo alemão e as manifestações racionalistas (sobretudo com a utilização de meios e finalidades) e a sedução radical pela tecnologia moderna que alguns destes autores demonstram. Posteriormente, Herf recoloca a questão em novos moldes, delimitando-a eticamente, num artigo essencial: "Uma nova análise do modernismo reaccionário. Os nazis, a modernidade e o ocidente" incluído in Zeev Sternhell (org.), O eterno retorno. Contra a democracia a ideologia da decadência, ob. cit., pp. 169-204.

(135) Vide P. Archer, "Ao princípio era o Verbo. O eterno retorno e os mitos da historiografia integralista", Revista de História das Ideias, vol. 18, 1996, pp. 231-243; para uma visão abrangente das concepções historiográficas, cf. idem, "Memória mítica da Nação - o caso do Integralismo Lusitano", Vértice, II série, n. ${ }^{\circ}$ 61, Jul.-Ago. 1994, pp. 51-66.

${ }^{(136)}$ Cf. António Sardinha, v.g., Da hera nas colunas, Coimbra, Atlântida, 1929, p. 9. 
e idólatras), cuja evidente ressonância messiânica, credora de um messiannismo romântico que Oliveira Martins instaurara, diria Sérgio(137) ("metafísica" da auto-redenção da natureza e da natureza humana, dirá Lourenço $\left.{ }^{(138)}\right)$ embora teoricamente negada, era texto após texto reforçada ${ }^{(139)}$. O mugense seria a descoberta de um equivalente deus obscuro da raça ${ }^{(140)}$, objecto "primordial" (Grosby) utilizado para uma outra sacralização (étnica e simbólica: raça de heróis) e como estratégia de reforço de laços e de afectos ${ }^{(141)}$ - enquanto se procurava a hegemonização política da religião tradicional - que fundamentaria o discurso do nacionalismo etnológico, mas não a violência do nacionalismo étnico, que foi progressivamente submergido por um nacionalismo religioso. De qualquer modo, o hispanismo serviria como ponto de fuga teórico para o ensimesmamento e como tese de recusa à "diminuição" das perspectivas históricas (e geográficas, económicas, etc.) da sociedade portuguesa; e criava, sobre uma estrutura atemporal, a perspectiva de um "território mítico" no qual assentaria a refiliação da ancestralidade comum (Anthony Smith), ao religar, numa dualidade "mística" e sob uma forma cultural, o povo e a terra, que é apanágio não exclusivo do discurso tradicionalista, senão de todo o nacionalismo ${ }^{(142)}$, acentuando, evidentemente, o carácter messiânico do nacionalismo integral e o seu "milenarismo político", resposta que uma sociedade periférica (marginal, no modelo explicativo de Kedourie, e de Smith $\left.{ }^{(143)}\right)$, encontrava, no contexto do capitalismo europeu (do qual Portugal se excluía, país ruralizado em vias de industrialização, pois que não encontrava mais assento - desde o século XVIII no grupo das "grandes nações"). E numa altura em que a aceleração da história, a acumulação e produção dos bens, evidenciava o tempo lento e o estado de subdesenvolvimento estrutural em que o país se encontrava.

(137) António Sérgio, "Interpretação não romântica do sebastianismo", Ensaios, I, Lisboa, Sá da Costa, 1971, p. 242.

(138) Eduardo Lourenço, Portugal como destino..., ob. cit., pp. 139-140.

(139) Veja-se o epílogo desta tese em Hipólito Raposo, "Portugal dos portugueses", in Pátria morena, Porto, Livraria Civilização, 1937, pp. 297-308.

${ }^{(140)}$ Anthony D. Smith, Nacionalismo y modernidad, ob. cit., (analogicamente: comentário a Kedourie) pp. 191-195.

(141) Idem, ibidem, p. 279.

${ }^{(142)}$ J. M. Sobral, "A formação das nações e do nacionalismo", Análise Social, XXXVII, ob. cit., p. 1102; Anthony D. Smith, La identidad nacional, ob. cit., p. 83.

${ }^{(143)}$ Anthony D. Smith, Nacionalismo y modernidad, ob. cit., pp. 191-195. 
Só se compreende o rumor do êxtase nacionalista que está em crescendo desde os finais do século XIX até 1940, se for escutado o longínquo eco do capitalismo europeu ${ }^{(144)}$ e o desfasamento que este produz numa sociedade periférica, que não está em plena crise capitalista, senão na difícil encruzilhada da modernidade ${ }^{(145)}$. Sob o ponto de vista da teoria política talvez se possa afirmar que o hispanismo é, pela negativa, a percepção de que ambas as sociedades ibéricas se encontram desfasadas dos ritmos de crescimento europeu e bloqueadas nas suas perspectivas históricas. A ideia da constituição de um grande espaço que preserve as especificidades ibéricas é, assim, um conceito político estratégico mais defensivo do que ofensivo. No contexto da teoria dos grandes espaços europeus o paniberismo não é, como o pangermanismo ou o paneslavismo, ou a latinité, uma proposição imperial, pois é, para além de uma ordem puramente mítica (essencial para a fundamentação política), o momento de afirmação de um espaço defensivo colonial do Atlântico Sul (garante da recíproca independência económica e política ibérica). Além disso,

${ }^{(144)}$ Esta posição de subalternidade e do estado de subdesenvolvimento português continua a acentuar-se nos inícios do século $X X$ : se é verdade que a mesma mobilização de interesses (económicos, políticos, estratégicos) que conduzem directamente ao ultimatum de 1890 se constituíram como factor determinante na queda da Monarquia, também é verdade que, persistindo, acabarão por liquidar a República. Talvez não se possa falar apenas aqui em ultimatum-mas em crónica subalternidade no quadro europeu. Por isso, outros factores têm de ser, razoavelmente, admitidos no quadro da emergência do nacionalismo (1820-1974), quer do nacionalismo regenerador (liberal do século XIX, republicano) quer do nacionalismo autocrático antiliberal, que surgem, ambos, como resposta - ou argumento? - a uma crescente situação de agravamento das condições de desajuste, subalternidade estratégica económica, diplomática, política, militar, cultural, face à crescente dominação político-económica da Europa dos Impérios, e que se tinha verificado ao longo de todo o século XIX: invasões militares, perturbações e guerras civis, ameaças às possessões coloniais (independência do Brasil), ultimatos $(1801 ; 1857 ; 1890)$, deficit estrutural da balança de pagamentos, incapacidade de modernizar a agricultura e de estruturar um processo industrializador, baixíssima alfabetização, sistemas de ensino médio e superior desajustados e insuficientes, acentuada taxa de emigração (1860-1975), pauperismo, mentalidade despesista, consumo supérfluo, ausência de capital e de investimento. Se o liberalismo e o romantismo parecem ser a fase original e construtiva da ideologia nacionalista, então, a ditadura de Salazar representa a sua fase terminal, ofensiva e destrutiva.

${ }^{(145)}$ Cf. Elia Kedourie, Nacionalismo, ob. cit., pp. 117-118. 
permitiria eliminar, ou atenuar, a pulsão segregacionista e racista do jus sanguinis em termos da função integradora do jus soli e do ecumenismo religioso. É este facto que permite explicar como os factores de segregação (o racismo e o antisemitismo) foram soterrados pela retórica integracionista da direita contra-revolucionária, tradicionalista e legitimista. Por último, anulava o carácter estritamente "regional" do nacionalismo português no contexto europeu, criando perspectivas supranacionais que, bem vistas as coisas, entravam em contradição com a própria fundamentação ideológica do nacionalismo.

Ora, a efectivação da ucronia passaria pela ditadura e, nesse aspecto, para Sardinha, o poder fascista ou a revolução soviética significavam já, embora transitoriamente, a passagem ao acto. Tal constatação evidencia alguma reaproximação ao discurso (não ao percurso) de Georges Sorel, em evidente rota de atracção à revolução soviética, pois que a lia como a "salvação" erguida contra as "plutocracias democráticas" e o "cinismo triunfante da burguesia"(146), o que o levará a escrever, logo em 1919, Pour Lénine. Também para Sardinha era a própria ideia de ditadura necessária, e correspondia "ao instinto vital de conservação das pátrias europeias", no interior da qual o gremialismo funcionaria como "eixo da reconstrução futura", pois o "direito social" fundamenta a soberania ${ }^{(147)}$, repondo a necessária solidariedade no tecido social, surgindo "do apelo unânime, tanto da inteligência como da produção, para a coordenação comum de um chefe" e acrescentava: "na verificação de semelhante fenómeno Lenine e Mussolini equivalem-se". Por isso, também a crise do estado demo-liberal daria lugar ao "estado custódia", "fiel dos diversos pluralismos com que a sociedade volta a exprimir-se" depois do desaire do "romantismo político"(148). Mas a praxis marxista caíra, segundo Sardinha, no dogma oposto ao da revolução francesa, negando individualidade humana ao combater o individualismo e desprezando a "soberania social" da família, do município e da corporação - referindo-se à inorganicidade, à destruição da família tradicional, ao materialismo filosófico -, caíra, em suma, no "estadismo", género da "asfixiante opressão burocrática", como escreve já depois de 1922, num texto fundamental e, com estranha frequência, mal lido ${ }^{(149)}$. Sardinha, Almeida Braga

\footnotetext{
${ }^{(146)}$ Cit. por Michel Winock, O século dos intelectuais, ob. cit., p. 149.

${ }^{(147)} \mathrm{Cf}$. António Sardinha, Da hera nas colunas, ob. cit., p. 41 e 42.

${ }^{(148)}$ Idem, ibidem, p. 21. Sublinhado nosso.
} 
(e não Rolão Preto, ou Monsaraz), H. Raposo falam, contra o "mito da igualdade", na necessidade de preservar os diversos pluralismos como condição necessária à reconstrução da sociedade ucrónica. Compreende-se porque, em 1942, Raposo chegará a escrever (o que, entre outros textos, lhe dará direito a internamento nos Açores): "ultimamente, nas sessões de propaganda, o punho deixou de ser fechado e a mão pareceu estendida, no ardil de atrair os próprios católicos" ${ }^{\prime(150)}$. O único Absoluto deixara de ser, definitivamente, a conquista do poder político. Era a conquista do "território sagrado" reivindicado como condição única para uma "economia global de salvação"(Cherniavsky, Hastings $\left.{ }^{(151)}\right)$. O ódio ao presente "ateu" e "materialista" e ao "capitalismo internacional" conduzira, num duplo sentido, o integralismo numa revisão eufórica e heróica do passado (memórias, história, tradições), impelindo-o para uma espécie de milenarismo político, impulsionado, sem dúvida, por um sentimento de autoemancipação (ou de autonomia, que parece muito arreigado) do quadro geral do capitalismo europeu do início do século, atingindo, no limite, o que se pode chamar "fanatismo escatológico"(152).

Em suma, na ucronia, marcada num território limítrofe ao da mera exasperação reaccionária e dispositivo estratégico utilizado contra o pensamento utópico, racionalista, cosmopolitista e universalista, se jogam e se mesclam certo providencialismo com o messianismo vieirino e com o sebastianismo miguelino, a corrente do pensamento tradicionalista e contra-revolucionário com o positivismo de direita e o historicismo reaccionário europeu. E é no interior dessa ucronia, numa última fase, que se nota a crescente influência da gnosis cristã, uma res publica christiana oriunda dos confins da teorização eclesial e aperfeiçoada pela doutrina das encíclicas e do neotomismo (sobretodos, Maritain e Maulnier, depois, nos epígonos, Mounier). Contra a universalização da utopia revolucionária, contra o materialismo do século, contra o capitalismo da "selva escura" - "como num rasgo de inspiração dantesca a definiu Afonso Lopes Vieira", precisará Sardinha ${ }^{(153)}$ - a ucronia era a via para a afirmação do universalismo cristão e dum nacionalismo ecuménico, onde se

(149) Idem, ibidem, p. 22 ss.

${ }^{(150)}$ Hipólito Raposo, A insurreição da carne, Lisboa, Edições Gama, 1944, p. 109.

${ }^{(151)}$ Adrian Hastings, La construcción de las nacionalidades, ob. cit., p. 242.

(152) Anthony D. Smith, Nacionalismo y modernidad, ob. cit., p. 205.

(153).António Sardinha, Glossário dos tempos, ob. cit., p. 312. 
encerravam todas as perspectivas do devir histórico: entre as teorias contemporâneas e coșmopolitas da densa floresta e o retorno ecológico ao bosque, ao fumo medieval da cristandade e da cruzada, onde se condensa, também, a mitologia anti-industrial e anti-urbana que ganhara romântico consenso nas letras portuguesas, salvava-se a árvore particular. Há um lance finalista nesta reconciliação entre Natureza e história: a ruptura filosófica aprofundada por Hegel, que é a substância da consciência cultural da modernidade - e da visão trágica da história ${ }^{(154)}$-, entraria em colapso.

Eis porque a épica, e a epopeia, em concreto, seriam os géneros de uma narrativa histórica que nasceria do "princípio superior". Mas a epopeia era já, como na Odisseia, a viagem ao nostos, a narrativa do regresso à "pequena casa lusitana", a não se cumprir a visão "hispânica" do tal Portugal-Maior. Seja este dado que nos permita compreender como o ditirambo do princípio superior (o qual se destinava a induzir nas massas "o culto do Ideal"(155)) acabará por adquirir, no Estado Novo, a metamorfose de um "legal" instrumento de censura, acabando por sufocar toda hipótese narrativa ${ }^{(156)}$, remetendo a épica para o prolongamento de um subdesenvolvimento estrutural, estrangulando a história e as perspectivas do presente num fio invisível e lento (uma retórica da invisibilidade, escreveu José Gil) que atravessava a vida das pessoas e as celas das prisões. Por certo, nem mesmo quando tentou, foi António

${ }^{(154)}$ Cf. Hayden White, Metahistoria. La imaginación histórica en la Europa del siglo XIX, México, Fondo de Cultura Economica, 1992, pp. 111-113.

${ }^{(155)}$ Martinho Nobre de Melo, Para onde vamos? Um aspecto do problema nacional, ob. cit., p. 23.

(156) O "ideal moral" deve orientar toda a actividade das elites: "A Imprensa deveria ser apenas um instrumento nas mãos das elites, e na mesma medida em que o devem ser a Justiça, a Universidade, o Capital, a Produção, a Administração, as Forças Armadas" - cf. Carlos Selvagem, O problema das elites no mundo moderno, ob. cit., p. 25. Veja-se a correlação, no Estado Novo, entre elites e "ideal moral", v.g., para além dos mais conhecidos e interpretados, Oliveira Salazar, Discursos, I, $3^{\text {a }}$ ed., Coimbra, Coimbra Editora, 1939: a universidade como "fábrica espiritual portuguesa" e a noção de populismo antiaristocrático (pp. 302 e 304); formulação dos "altos e nobres sentimentos" (p. 309); Discursos, II, $2^{\text {a }}$ ed., passim, 1945: ordem e policiamento da "Revolução nacional" (pp. 66-69); Discursos, III, 2. a ed., passim, 1959: pensamento superior (p. 257), "valores espirituais do governo" (pp. 287-292); Discursos, IV, passim, 1951 (pp. 26-27): a gratidão do "povo" perante a "acção superior" de intelectuais e estadistas, etc. 
Sardinha alguma vez poder (político, burocrático, de estado) embora conquistasse, no forum dos intelectuais, direito a tribuna e a patibulo. Para gente de génio, ensinava Saint-Simon, o poder é um perigoso percalço que lhe faz perder a consideração e a autenticidade.

Em conclusão, reveja-se o andamento ternário que se propôs no estudo: (I) após ter encontrado num sistema crítico a sua função distorciva (diagnóstico e crítica da pretensa decadência existencial e filosófica à escala europeia e portuguesa, crítica radical ao racionalismo e à modernidade); (II) de ter modelado (e de ser modelada) por um movimento político que corporizou a sua função legitimativa (ou autolegitimativa, com a emergência dos intelectuais na estruturação de órgãos de difusão e de debate, travando uma específica luta cultural nacionalista); (III) a intelectualidade da direita contra-revolucionária encontraria na ucronia o seu "fechamento ideológico" e a sua função constitutiva (o acabamento conceptual) que evidenciava, no entanto, pela negativa, o desajuste material em que se encontrava Portugal face à Europa capitalista. Se a lição de Ricoeur, a propósito duma releitura de Weber, encontrar possibilidades de entendimento e de aplicação empírica ${ }^{(157)}$.

\section{Memorandum}

Duas notas à margem. A primeira é sobre a procissão das mitologias contemporâneas. Se é próprio da contemporaneidade a secularização e uma escatologia prometeica, perante a qual a queda das grandes cenografias utópicas é totalmente legível; e, se, perante essa derruição cenográfica, que é a própria história do século $X X$, irrompem pequenas utopias salvíficas que operam, por sua vez, novas deslocações de sacralidade ao proporem rituais de transcendência para uso próprio que se colocavam, nas sociedades tradicionais, no limiar da morte, ocorre, então, a intuição do poeta: afinal, se nós não existíssemos, como teríamos a certeza de que Cervantes era imortal? Esclareça-se. S. João da bíblica profecia e Ford Coppolla de Apocalypse now enganaram-se, ambos. O apocalipse ainda está aí, a cores, nunca mais acaba. Continuamos, talvez, a saber p. 330.

(157) Paul Ricoeur, Ideologia e utopia, Lisboa, Edições 70, 1991, pp. 324-325 ss., 
muito pouco das utopias e das ucronias do século $X X$, mas algo já sabemos: mesmo aqueles utopistas que foram mortos em esfinge nos "manuais científicos", parece ressuscitarem. Talvez tudo isto seja assim porque se pensas no futuro e o exprimes, todas as forças do presente se hão-de levantar contra os teus gestos, dizia um velho pensador. Talvez porque $o$ futuro é a aurora do passado, como queria Pascoaes, em excerto sempre pensado por Lourenço: é evidente que a discussão sobre identidade (que é, claro, uma discussão sobre identidades, sobre memórias socialmente vinculativas), afora dos muros do puro autismo e da paranóia nacionalista ${ }^{(158)}$, e da força dos pré-juizos (Taguieff), continua a revelar-se como um muito sério, muito útil e, desejavelmente, muito profundo debate de intelectuais. Outro século após Durkheim, suspeita-se, ainda, que o conceito de nação continue a ser uma ideia mística e obscura, pois os fundamentos metafísicos (e metahistóricos) do "político" na comunidade nacional remetem para o primordial, para os deuses obscuros das relações de sangue e, em última análise, invocam os deuses protectores da terra, da nação, o que nos fará interrogar: de que lado estiveram, ao longo de todo esse tempo, os deuses?

A segunda nota é sobre miragens e poços de ar. Apesar de sabermos que, ontologicamente, o ser humano é uma invenção recente, e de admitirmos que nem sempre a realidade existiu (Derrida, Baudrillard), continuamos a suspeitar que não podemos viver sem a procura de realidade que nunca existiu. Que a vida é demasiado caótica para sobrevivermos sem sonhos nem utopia (contudo, quando se fitam em demasia os céus, outros rapidamente retiram da terra os frutos, ensinava o sábio da Arte de furtar, que é uma arte de pensar). Mas mal se tenta realizar a utopia, ou simplesmente acordamos, suspeita-se que não nos deixa a utopia (que-já-não-é) viver a nós. Por isso, o utopista é alguém que, não sendo normalmente o prisioneiro, tem a enorme vontade (tão sistemática, que parece doentia) de fugir da prisão. $O$ intelectual (normalmente, um prisioneiro, contratado) é aquele que o estuda com pacientes anotações e, por vezes, o consegue, à distância, acompanhar na fuga.

${ }^{(158)}$ Eduardo Lourenço, A nau de Ícaro, seguido de Imagem e miragem da lusofonia,

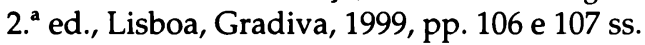

